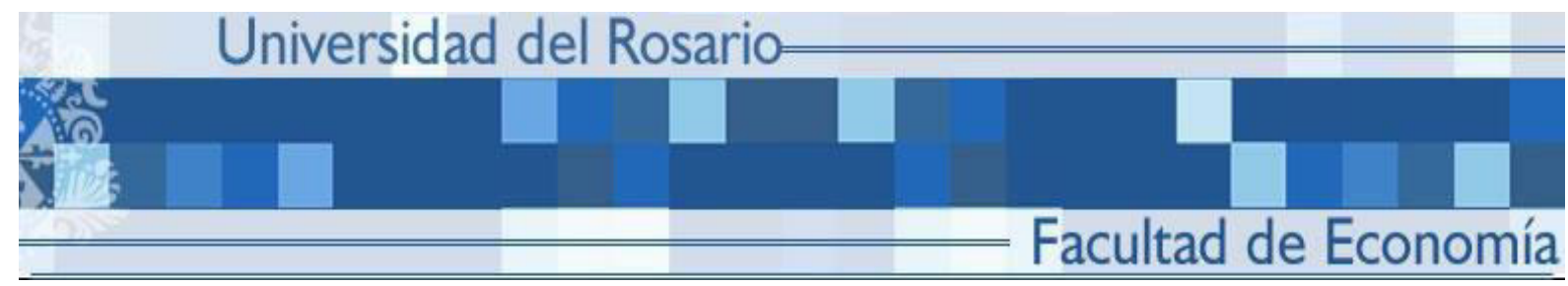

The Internal Labor Markets of Business Groups

Cristobal Huneeus

Federico Huneeus

Borja Larrain

Mauricio Larrain

Mounu Prem

SERIE DOCUMENTOS DE TRABAJO

No. 242

Noviembre de 2019 


\title{
The Internal Labor Markets of Business Groups*
}

\author{
Cristobal Huneeus \\ Unholster
}

\author{
Federico Huneeus \\ Yale \& Central Bank of Chile
}

\author{
Borja Larrain \\ PUC Chile
}

\author{
Mauricio Larrain \\ Mounu Prem \\ PUC Chile ES CMF Chile \\ U. del Rosario
}

\begin{abstract}
This paper provides novel micro evidence of labor mobility inside business groups. We show that worker flows between group firms are significantly more prevalent than between unaffiliated firms. We also find that groups respond to changing business conditions by reallocating top-occupation workers across affiliated firms. The wages of top workers increase as they move within the group. Internal labor reallocation is stronger when the worker's origin firm controls the destination firm and in more complex hierarchical structures. Our results are consistent with the hypothesis that groups ease the transfer of intangible inputs, such as management practices, across firms.
\end{abstract}

Keywords: Internal labor markets; business groups; ownership; intangible inputs.

JEL Codes: G32; J60

\footnotetext{
*October 29, 2019. We thank comments and suggestions from Heitor Almeida, Will Dobbie, Ran Duchin, Gregor Jarosch, David Lee, Alex Mas, Adrien Matray, Atif Mian, Will Mullins, Gabriel Natividad, Imran Rasul, Esteban Rossi-Hansberg, Rui Silva (WFA discussant), David Schoenherr, Geoffrey Tate (FinanceUC discussant), Robert Townsend, Liu Yang (CSEF discussant), conference participants at the 2019 WFA meetings, the CSEF Conference on Finance, Labor and Inequality, the 14th International Conference of FinanceUC, and the CEPRILO-IGC-UNIGE Conference on Labor Markets in Developing Countries, and seminar participants at the UCLA Anderson School of Management, UCSD Rady School of Management, Princeton University, and Universidad de los Andes. We thank the Ministerio del Trabajo de Chile for coordinating the access to an anonymized version of the unemployment insurance dataset. Borja Larrain acknowledges funding from Proyecto Fondecyt Regular 1180593. Federico Huneeus acknowledges funding and support from the International Economic Section (IES), the Simpson Center for the Study of Macroeconomics, the Program in Latin American Studies (PLAS) and the Fellowship of Woodrow Wilson Scholars, all from Princeton University. Corresponding author: Mauricio Larrain, mauriciolarraine@gmail.com.
} 


\section{Introduction}

Business groups are common corporate structures around the world. More than half of all listed firms in emerging markets, and a sizable fraction in many developed countries, are affiliated to business groups (Khanna and Yafeh 2007; Morck, Wolfenzon, and Yeung 2005). Business groups consist of legally independent firms controlled by the same ultimate owner. As an example, Figure 1 shows the corporate structure of Antarchile, one of the largest business groups in Chile and controlled by the Angelini family. There are several reasons that can explain the existence of these complex ownership structures. One set of explanations argues that, unlike stand-alone firms, business groups create factor markets between affiliated firms to alleviate frictions. Along these lines, there is growing evidence that business groups transfer capital between firms to overcome financial constraints. ${ }^{1}$

However, we still know very little about other factor markets in business groups, in particular internal labor markets. Labor markets are affected by several frictions, from transaction costs in hiring and firing to asymmetric information and imperfect insurance. The use of internal labor markets could allow business groups to overcome these frictions, i.e., hiring (letting go) workers from (to) the internal labor market could be cheaper than from (to) the external labor market. The ability to use internal labor markets would then give group firms an advantage over stand-alone firms. We provide evidence that business groups actively use internal labor markets. We also provide suggestive evidence that internal labor mobility benefits the business group as a whole. Overall, we identify and quantify a novel advantage of business groups.

We use a detailed matched employer-employee dataset covering the universe of workers in Chile between 2004 and 2015. Our data allows us to follow workers as they switch jobs from one firm to another. We then merge our employment data with ownership information for the firms, which allows us to determine business-group affiliation. Our unit of observation is a pair of firms in a moment in time for which we observe a positive worker flow. We classify firm pairs into affiliated firms (those belonging to the same business group) and unaffiliated firms.

To test for internal labor mobility we start by comparing worker flows between affiliated

\footnotetext{
${ }^{1}$ See Gopalan, Nanda, and Seru (2007), Boutin, Cestone, Fumagalli, Pica, and Serrano-Velarde (2013), Buchuk, Larrain, Munoz, and Urzúa (2014), Almeida, Kim, and Kim (2015), and Buchuk, Larrain, Prem, and Urzúa (2019).
} 
and unaffiliated firms. Neoclassical theory suggests that worker flows between firms should be unrelated to ownership structure. Instead, we find that worker flows between affiliated firms are significantly more prevalent than between unaffiliated firms: on average, a group firm sends five times more workers to a firm in the same group than to an unaffiliated firm. The effect is stronger for top-occupation workers, which we define as those in the top quartile of the within-firm wage distribution. The effect remains significant after controlling for origin firm, destination firm, and year fixed effects.

Because business group affiliation is a choice variable, affiliated firm pairs could be different from unaffiliated firm pairs for reasons other than common ownership. For example, firms belonging to the same group could be located geographically closer to each other. In that case, the higher prevalence of worker flows between affiliated firms could be the result of geographical proximity and not common ownership. To partially address spatial proximity we include location-pair-times-year fixed effects in our base regression; and industry-pair-times-year fixed effects to control for industrial proximity. Our results remain unchanged: we still observe significantly more worker flows between affiliated than unaffiliated firms.

The access to internal labor markets should be particularly valuable when business conditions change across firms. Reallocation in response to shocks allows us to evaluate the underlying logic of internal labor flows. First, we follow the finance literature on internal labor markets (Tate and Yang 2015) and use as proxy for business conditions the change in industry-level Tobin's Q (the ratio between the market and book value of assets, obtained from listed firms). We compare worker mobility between affiliated and unaffiliated firms as a function of shocks in Tobin's Q across firms. Imagine that a group firm receives a negative shock to its industry. Neoclassical theory suggests that this firm should reduce labor demand and send workers to other firms in the market, regardless of whether they belong to the same group or not. We find instead that, in response to a negative shock relative to other firms, the group firm sends more workers to other firms in the same group than to unaffiliated firms. We find $12 \%$ more reallocation of topoccupation workers towards same-group firms than to unaffiliated firms in response to relative changes in Tobin's Q.

The labor reallocation test has the advantage of allowing us to include firm-pair fixed effects, which control for all time-invariant differences between affiliated and unaffiliated pairs. By 
including firm-pair fixed effects we can compare the reaction to shocks within affiliated and unaffiliated pairs. The regression with firm-pair fixed effects confirms that group firms actively use internal labor markets, especially in the case of top-occupation workers. In fact, we find very similar responses to Tobin's Q in the specification with pair fixed effects than for the specification with separate origin and destination firm fixed effects. This suggests that our results are not driven by unobserved heterogeneity between affiliated and unaffiliated pairs.

As a second measure of changes in business conditions we use firm-level international trade shocks. $^{2}$ This measure is novel to the finance literature and has three important advantages over Tobin's Q. First, because Chile is a small and open economy, international trade shocks, unlike Tobin's Q changes, are plausibly exogenous to worker flows. Second, trade shocks are more granular and precise, because they are defined at the firm level, instead of at the industry level. Third, trade shocks can be measured for private firms, while Tobin's Q is focused on listed firm which represent only a minority of firms in our sample. The downside is that trade shocks apply only to firms that are exposed to international trade. We merge our employment and ownership data with customs data, which contains detailed information on firms' exports and imports. We define trade shocks using a Bartik-type strategy: for each firm, we compute the weighted average of the change in world prices of the goods the firm exports (or imports), where the weights correspond to the initial share of the goods exported (or imported) by the firm. The results using trade shocks reaffirm our previous findings. In response to trade shocks there is $20 \%$ more reallocation of top-occupation workers towards affiliated firms than to unaffiliated firms. Importantly, the wages of top-occupation workers increase by close to $6 \%$ as they move within the group in response to these shocks.

We next restrict our comparisons solely to affiliated firms, i.e., to worker flows within business groups. Following the logic of Stein (1997)'s internal capital market tests, we study whether the owner of a business group channels internal resources towards firms for which the appeal of investing suddenly increases. Even while focusing on flows inside the same group, we find that top-occupation workers move towards firms that face the most favorable business conditions.

After documenting the extent of internal labor mobility in business groups we explore its potential drivers. We first study standard frictions that can make internal labor markets more

\footnotetext{
${ }^{2}$ See Autor, Dorn, and Hanson (2013); Hummels, Jørgensen, Munch, and Xiang (2014).
} 
convenient than external labor markets: transaction costs, diversification, imperfect insurance, and asymmetric information. We provide various pieces of evidence against the relevance of these frictions, at least in our setup. However, since our proxies for frictions are imprecise we cannot rule out any of them. Instead, we provide evidence consistent with a new hypothesis developed in this paper, which we label the "intangible inputs" hypothesis. This hypothesis builds upon the recent work of Atalay, Hortaçsu, and Syverson (2014) and Ding, Fort, Redding, and Schott (2019). The underlying friction in this case is the imperfect contractibility of intangible inputs.

According to our intangible inputs hypothesis, common ownership facilitates the transfer of intangible inputs between firms. Intangibles (e.g., management practices, knowledge, knowhow, organizational culture) are hard to transfer because they are often embedded in workers. Hence, an explanation about intangibles can account for the concentration of reallocation and wage increases among top-occupation workers for whom intangibles are more relevant. Business groups have an advantage over stand-alone firms because, by virtue of the control rights over multiple firms, they reduce the specificity of worker non-contractible investments to acquire these intangibles. In addition, control in groups is usually exercised in steps or layers. Hierarchies allow workers to better use their knowledge -an intangible and incontractible input- by delegating and coordinating with other workers. Business groups provide larger hierarchies on which workers can further leverage their knowledge. In line with the importance of hierarchical structures, we find that labor reallocation is stronger when the firm of origin directly controls the firm of destination of the worker, and when the hierarchical structure is more complex. The ease to transfer top-occupation workers between firms, with their embedded intangibles, is a novel advantage of business groups that we highlight in this paper.

Finally, we study the firm-level consequences of internal labor mobility. First, we show that international trade shocks lead to higher wage growth and lower employment growth in group firms than in stand-alone firms. ${ }^{3}$ Second, using a synthetic control approach we study the effects on the average wage, our proxy for productivity, of the group firms that receive and send top workers. We find that the average wage goes up when a group firm receives a top-occupation worker from within the group. On the other hand, the average wage of the group firm that sends the top-occupation worker remains unchanged. Because the overall wage of the business

\footnotetext{
${ }^{3}$ This reduced-form evidence is consistent with the recent work of Faccio and O'Brien (2017).
} 
group is a weighted average of the wages of the different group firms, these two findings suggest that internal reallocation increases group-level productivity. Together with the fact that group firms send workers towards the affiliated firms with better business conditions, the findings in our paper suggest that internal labor reallocation adds value to the business group as a whole.

Our results contribute, first and foremost, to the literature on business groups (Khanna and Yafeh 2007). The internal labor markets of business groups are less studied than internal capital markets, but potentially equally important to understand the rationale behind the formation of business groups. Our paper, together with Belenzon and Tsolmon (2016), Faccio and O'Brien (2017), and Cestone, Fumagalli, Kramarz, and Pica (2017), belongs to the nascent study of internal labor markets in groups. The first two papers use firm-level data in a cross-country setting. Our paper is closer to Cestone, Fumagalli, Kramarz, and Pica (2017), who also use employer-employee matched data for France. We provide four main novelties compared to these papers. First, our empirical strategy focuses on the response of business groups to firm-level trade shocks, taking advantage of the small and open nature of the Chilean economy. These shocks are arguably exogenous and, at the same time, relevant proxies for changing business conditions. Second, our finding of increasing wages for top-occupation movers speaks against the insurance hypothesis, highlighted by Cestone, Fumagalli, Kramarz, and Pica (2017), but is in line with recent evidence on the pass-through of firm-level shocks to workers (Garin and Silverio 2018; Kline, Petkova, Williams, and Zidar 2019). Third, in order to test for mechanisms, we map the inner structure of business groups in a detailed way. For instance, we test for the importance of direct control links and the hierarchical structure of the group. Finally, our hypothesis that groups ease the transfer of intangible inputs embedded in top-occupation workers underscores a new advantage of business groups.

Our paper also contributes to the literature on the internal labor markets of conglomerates with fully-owned subsidiaries or plants (Giroud and Mueller 2015; Tate and Yang 2015; Silva 2017). Although similar mechanisms apply to both conglomerates and business groups, a key difference is that worker flows are within a firm in conglomerates and between firms in business groups. Different units in a conglomerate share a common balance sheet, they typically have integrated human resources departments, distribution channels, and so on. Such integration blurs firm boundaries. In business groups the controlling shareholder is often the only link between 
firms that are independent corporations. Both ownership structures provide significant control rights, but without erasing firm boundaries in the case of business groups as it happens with conglomerates. This subtle difference can have an impact on the nature of internal labor markets. In particular, our results suggest that internal labor markets in business groups alleviate market frictions among top-occupation workers, while previous literature on conglomerates and multi-plant firms finds effects on all types of workers. From the point of view of control rights (Hart 2001), it makes sense that the impact of ownership is noticed on top-occupation workers because exercising control often means removing executives from management positions. In conglomerates, labor flows are influenced by the control rights of owners, but also by the economies of scale associated with conglomeration.

The remainder of the paper proceeds as follows. Section 2 describes the data and reports preliminary evidence. Section 3 presents the main evidence in support of the existence of internal labor markets. Section 4 tests for different rationales behind internal labor mobility. Section 5 discusses the firm-level effects of internal labor markets. Section 6 concludes. The Appendix provides supplementary data description and results.

\section{Data Sources and Preliminary Evidence}

We combine three data sources to study the internal labor markets of business groups. First, we use a matched employer-employee dataset to identify worker flows between firms. Second, we use a business-group dataset to link the firms in our sample. We classify firms into businessgroup firms and stand-alone firms. Third, we construct our two measures of shocks to business conditions using (i) data on financial statements and stock prices for listed firms, and (ii) customs data with export and import price shocks. ${ }^{4}$

\subsection{Matched Employer-Employee Dataset}

Chilean firms are required by law to pay a fraction of workers' monthly wages into an individual savings account and a common fund that can be used by all workers in case of unemployment. The unemployment insurance system is managed by a private entity that keeps the Unemploy-

\footnotetext{
${ }^{4}$ The Appendix describes in detail the cleaning and merging procedures used and some limitations of the three datasets.
} 
ment Insurance dataset. ${ }^{5}$ We obtained this data for the period between 2004 and 2015. This dataset provides information of the wage for each employer-employee relationship. Firms also report their main industry and the gender and birth date of each worker. The dataset does not report information of the professional category or occupation of the worker. Past research on employer-employee matching has used similar datasets from other countries, such as Germany and Portugal (Card, Heining, and Kline, 2013).

This dataset has three features that are relevant for our study. First, it covers the entire (formal) private labor market in Chile. Second, because Chile's administrative datasets have unique tax IDs for both workers and firms, we can keep track of both across time and merge them to other datasets. This dataset includes listed and private firms. We use the listed firms to merge the labor dataset with the business group dataset. Finally, given that we have the employer-employee relationships, we have the entire wage distribution within and across firms.

\subsection{Business Group Dataset}

Chilean listed firms are required by law to report financial statements and ownership structures to the local stock market regulator (Financial Markets Commission). From the universe of listed firms, we define a business group as a set of two or more firms with a common controlling shareholder (Buchuk, Larrain, Munoz, and Urzúa 2014). Financial statements typically report links between corporations, but not the names of the ultimate shareholder. We identify the controlling shareholder by checking the composition of boards, annual reports, and the financial press. Controlling shareholders are families, foreign multinationals, or small groups of large investors who act in a coordinated way. The state is not a relevant controlling shareholder of listed firms in Chile. The ownership structures of business groups are stable across across long periods of time in the Chilean market (Donelli, Larrain, and Urzúa 2013).

Using the information reported by the listed firms we can track the private firms that are related to the listed firms, and hence that also belong to business groups. Ownership links with private firms are reported in two ways. First, there is a list of firms that consolidate with a listed firm. Accounting consolidation means that the firm exerts a controlling influence over the other firm. In practice, consolidation typically implies an ownership stake above $50 \%$. Second,

\footnotetext{
${ }^{5}$ The U.S. equivalent to this dataset is the U.S. Longitudinal Employer-Household Dynamics (LEHD).
} 
there is a list of related investments made by a listed firm. These are firms where the listed firm has a large and permanent investment, although the type of influence does not imply accounting consolidation. Related investments typically involve ownership stakes between $10 \%$ and $50 \%$. Because ownership stakes are significant we consider that the firms in related investments also belong to a group if their parent has been identified as a group firm.

Using all the previous information we define the firms -listed and private- that conform each business group. During our sample period, 2004-2015, we identify 29 business groups covering 93 listed firms and multiple private firms. Figure 1 provides an example of a business group in our data. The group is controlled by the Angelini family and has five listed firms: the holding company -Antarchile- at the top of the pyramid, plus four firms in the second layer of the ownership structure.

\subsection{Data for Shocks to Business Conditions}

We use two measures of shocks. First, we follow the finance literature and use changes in industry-level Tobin's Q (Tate and Yang, 2015). We collect data from Economatica, which provides financial statements and stock market information for the universe of listed firms in Chile. For each listed firm, we calculate Tobin's Q as the ratio between the market and book value of assets. The market value of assets is equal to the market value of equity plus the book value of debt. Next, we calculate the average Tobin's Q across all listed firms in each industry each year. We use the industry classification given by the employer-employee data at the twodigit level (20 industries). Finally, for each firm in our employer-employee dataset (listed and private), we define the shock as the percentage change in Tobin's Q for the industry to which the firm belongs.

Our second measure of shocks follows the international trade literature and consists of changes in firm-level export and import prices (Autor, Dorn, and Hanson 2013; Hummels, Jørgensen, Munch, and Xiang 2014). This is a novel approach for the literature on business groups. We use two sources of trade data to construct the shocks. The first provides the trade

activity of Chilean firms at annual frequency. Chilean firms report detailed import and export activity to the customs authority. Each firm reports the quantity and value of every international transaction with information at the product-country level combination. Product definition is at 
the six-digit level from the Harmonized System.

With the customs data, we could compute unit prices of both exports and imports at the firm level. However, and although Chilean firms are small relative to global markets, some of the variation in these unit prices could capture the specific characteristics of local firms. In order to avoid endogeneity concerns we build international versions of these unit values for every product-country combination. Following the trade literature, we ignore trade flows with Chile when building these prices. We use trade data at the product-country level coming from a repository of official trade information collected by the UN Statistical Division, Comtrade. We define the firm-level trade shocks as:

$$
\Delta \operatorname{Price}_{i t}^{k}=\sum_{j} s_{i j 0}^{k} \Delta \operatorname{Price}_{j t}^{G, k}
$$

where $k=$ \{export, import $\}, i$ index firms, $t$ time, and $j$ are product-country combinations, $\operatorname{Price}_{j t}^{G, k}$ is the log global unit price of a product-country pair $j$ being exported (imported), and $s_{i j 0}^{k}$ is the share of product-country $j$ relative to all the corresponding activities $k$ of firm $i$ in the initial year (2004). Overall, this strategy is similar to a Bartik-type empirical strategy (Bartik 1991; Blanchard and Katz 1992). A decrease in export prices represents a negative shock for an exporting firm; an increase in import prices represents a negative shock for an importing firm. ${ }^{6}$

Because most trade flows are concentrated in firms that simultaneously export and import, we assess the relative importance of each activity for firms. We compare exports and imports to firms' wage expenditures. We find that, on average, firms spend $\$ 1.3$ in imports and receive $\$ 2$ in exports for every dollar spent in wages. This suggests that export price shocks are more relevant than import price shocks in our sample. ${ }^{7}$

\footnotetext{
${ }^{6}$ Table A.1 in the appendix presents basic descriptive statistics of the volatility of these shocks and the probability of observing large shocks. It shows that exports shocks are more volatile in manufacturing and mining, and that they are particularly large during the emerging markets' boom of 2004-2007.

${ }^{7}$ We compute the industry composition of the labor dataset, of the merged labor-business groups dataset, and of the merged labor-business groups-trade dataset (Appendix Figure A.1 provides details). Relative to the labor dataset, the business groups and trade datasets are less intensive in services and more intensive in manufacturing, which is expected from the focus on firms that are exposed to international trade shocks. Despite the overall importance of copper mining in Chile, this industry represents less than $5 \%$ of our employment data because this industry is relatively more capital-intensive and because many of the large mining firms are state-owned, and hence are not part of the labor dataset.
} 


\subsection{Summary Statistics}

Table 1 reports summary statistics for our broad sample, based on the merged labor-business groups data. We have on average 88,670 firms per year, of which 252 are business-group firms and 88,418 are stand-alone firms. We have data on roughly 3.5 million workers per year, of which 103,547 work in business-group firms and the rest work in stand-alone firms. Group firms are larger than stand-alone firms: the average group firm has 411 workers on its payroll, while the average stand-alone firm has only 38 workers.

Our main unit of analysis is the bilateral flow of workers between two firms. For each pair of firms we compute the number of workers moving from an origin firm to a destination firm every year. We define the worker flow as the number of workers moving from the origin firm to the destination firm, relative to the total number of workers that leave the origin firm for other firms that year. ${ }^{8}$ As in Cestone, Fumagalli, Kramarz, and Pica (2017), we focus on firm pairs in which the origin firm belongs to a business group. Table 1 shows that there are close to 86,000 unique firm-pairs where the origin firm is a group firm. Some of these firm pairs have repeated flows during the sample. Out of the 9,809 unique pairs in the average year, there are 556 pairs where both the origin and destination firms belong to a group; the remaining 9,253 firm pairs have a group firm as origin and an unaffiliated firm as destination.

Appendix Table A.2 reports summary statistics for our merged labor-business groups-trade dataset, which restricts the sample to firms that engage in international trade. As expected, the average firm that engages in international trade is larger (in terms of workers) than the average firm in the economy (Melitz, 2003; Bernard, Eaton, Jensen, and Kortum, 2003).

\subsection{Preliminary Evidence}

Table 2 reports summary statistics for worker flows. Out of 100 workers a group firms sends to other firms in a given year, 2.1 workers are sent to the average unaffiliated firm, while 11.5 workers are sent to the average firm in the same group. ${ }^{9}$ Hence, on average, a group firm sends

\footnotetext{
${ }^{8}$ We can also normalize the worker movement by the total number of workers absorbed by the destination firm. We follow the literature and normalize by the total number of workers released by the origin firm (Jacobson, LaLonde, and Sullivan 1993; Davis and von Wachter 2011).

${ }^{9}$ Appendix Table A.3 shows the strong statistical significance of these differences in our full sample and the sample of exporters and importers. Average worker flows between affiliated and unaffiliated firms do not sum up to one because these numbers are defined at the firm-pair level. In order for them to sum up to one, they need
} 
five times more workers to a firm in the same group than to an unaffiliated firm $(=11.5 / 2.1) .{ }^{10}$

We also report summary statistics across different segments of the within-firm wage distribution. Top-occupation workers are defined as the workers in the top quartile of the origin firm's wage distribution. When a group firm releases top-occupation workers, the worker flow towards the average firm in the same group is almost three times larger than towards the average unaffiliated firm (29.5\% versus $11.2 \%)$. We do not find similar results when defining top-occupation workers from the overall wage distribution in the economy. This implies that our findings are about top positions within a firm, rather than about high nominal wages.

Table 2 also reports summary statistics of wage changes. When a worker moves to another firm in the same business group, her wage increases by $12.1 \%$; while if she moves to an unaffiliated firm, her wage increases by only 3.6\%. Interestingly, top-occupation workers that move to unaffiliated firms see their wage actually decrease. ${ }^{11,12}$ The bottom panel of Table 2 shows that the slope of the within-firm wage distribution is similar for group and non-group firms. The wage of the top-quartile workers is 2.5 times the wage of the bottom-quartile workers in group firms and 2.1 times for the case of non-group firms.

\section{Internal Labor Markets at Work}

\subsection{Internal Labor Mobility On Average}

In Table 3 we study worker flows in regression format. We regress the worker flows between origin firm $o$ and destination firm $d$ on a dummy variable that takes the value of one if the firms belong to the same business group, and zero otherwise. We define the group dummy at the beginning of the sample to ensure that group affiliation is unrelated to subsequent changes in

to be scaled up by how many relationships a given firm has on each margin.

${ }^{10}$ If we further decompose the group of unaffiliated firms into other group firms and stand-alone firms (see Appendix Table A.4), we find that the flows are much larger within the same group (11.5\%) than to unaffiliated firms that belong to other groups $(3.1 \%)$. This highlights that flows within groups are larger not because all group firms belong to an environment that generally has more internal worker flows.

${ }^{11}$ These calculations only include changes for workers with wages that are not top-coded. The share of topoccupation worker flows with top-coded wages in our sample is $11.6 \%$. This only biases downwards the estimates of wage increases.

${ }^{12}$ In Appendix Table A.4, we show that when one opens the unaffiliated group into different group firms and stand-alone firms, one finds that the losses of wages are actually larger when moving outside of groups (-6.7\%) rather than moving to a different group (2.8\%). Only in the case of top-occupation workers, we find a relevant difference between workers that move between groups and within groups (2.8\% versus $8.5 \%)$. 
worker flows. Our baseline specification is the following:

$$
\text { Worker Flow }_{\text {odt }}=\beta \text { Same Group } \text { od }+\lambda^{\prime} \mathrm{X}_{\text {odt }}+\alpha_{o}+\alpha_{d}+\alpha_{t}+\epsilon_{\text {odt }} \text {. }
$$

We include a vector of origin firm and destination firm controls $\left(\mathrm{X}_{\text {odt }}\right)$, which also include business group characteristics (e.g., number of firms in the group); origin firm $\left(\alpha_{o}\right)$ and destination firm $\left(\alpha_{d}\right)$ fixed effects to control for all time-invariant firm characteristics; and year fixed effects $\left(\alpha_{t}\right)$ to account for annual common shocks to all firms. All of our regressions are at the annual frequency. We double cluster the standard errors of this regression, and all firm pair regressions, at both the origin-firm and destination-firm levels.

The main coefficient of interest is $\beta$, which captures the relationship between worker flows and business group affiliation. Under the neoclassical theory, $\beta=0$, because the fact that two firms are related through a common owner should not matter for worker flows, i.e., this is the labor-market version of the irrelevance proposition of Modigliani and Miller (1958). If, instead, business groups use internal labor markets, then we should find a positive and statistically significant $\beta$.

The results in Table 3 confirm the patterns of Table 2. When a group firm releases workers, the flow towards the average firm in the same group is 4 percentage points larger than towards the average unaffiliated firm (column 1). The effect is large and highly significant, accounting for a high fraction of the variation of worker flows. Note that in column 1 we control for the difference in the average wage between the origin and destination firms, which in principle should be a sufficient statistic to explain worker flows between firms. We also control for the level of employment of the origin and destination firms, of the business groups involved, and their respective number of firms. ${ }^{13}$

In columns 2 through 4 we focus on workers in different segments of the within-firm wage distribution. The effect of business group affiliation on workers at the top quartile of the distribution is around 1.8 times larger than for workers at the bottom quartile of the distribution $(=0.058 / 0.032)$. This result confirms that internal labor mobility is stronger among

\footnotetext{
${ }^{13}$ We control for the size of the origin and destination firms because worker dynamics (e.g., labor churning) vary with firm size. Likewise, it can be the case that worker flows between firms vary with the size of the origin and destination firms.
} 
top-occupation workers.

Because business group affiliation is a choice variable, affiliated firm pairs could be different from unaffiliated firm pairs for reasons other than common ownership. For example, firms belonging to the same group could be located geographically closer to each other. In that case, the higher prevalence of worker flows between affiliated firms could be the result of geographical proximity and not common ownership. Likewise, firms in the same group could be industrially more related to each other. For example, workers from the manufacturing sector might move more frequently to the mining sector than to other sectors because they have knowledge that is more useful in capital-intensive industries. If group firms are more concentrated in manufacturing and mining than stand-alone firms, then the higher prevalence of flows between them firms could be the result of industrial proximity and not common ownership.

To partially address these problems we include in Equation (3.1) location-pair-times-year fixed effects to control for spatial proximity; and industry-pair-times-year fixed effects to control for industrial proximity. We construct the location-pair fixed effects by using the municipality in which the origin and destination firms are located, and the industry-pair fixed effects using the two-digit industrial classification. ${ }^{14}$ We then interact the location-pair and industry-pair indicators with year indicators to control for potentially time-varying effects of location and industrial proximity. Table 4 reports the results. The effects remain unchanged: we observe significantly more worker flows between affiliated than between unaffiliated firms, and this effect is stronger for top-occupation workers.

\subsection{Internal Labor Mobility and Business Conditions}

Internal labor markets should be particularly valuable when business conditions change across firms. As a further test we study how the response of worker flows to changing business conditions depends on business group affiliation. Figure 2 illustrates the empirical strategy in graphical form. Firm $A$ is the origin firm of the worker and, for concreteness, it faces a negative shock. Firms $B$ and $C$ face the same positive shock. The difference is that firms $A$ and $B$ belong to the same business group, while firm $C$ is not affiliated to the group. The question is then whether

\footnotetext{
${ }^{14}$ Note that we do not have plant-level data and thus, the municipality of the firm corresponds to the location of the headquarter of the firm.
} 
the worker flow between $A$ and $B$ is larger than the flow between $A$ and $C$. This allows us to study not just internal mobility on average, but the logic underlying worker flows between affiliated firms. ${ }^{15}$

In econometric terms, we regress the worker flow between a pair of firms on the relative shocks between the two firms, the same-group dummy variable, and the interaction between the relative shocks and the same-group dummy:

$$
\begin{aligned}
\text { Worker Flow }_{o d t} & =\beta \text { Same Group }_{o d}+\gamma\left(\operatorname{Shock}_{d t}-\text { Shock }_{o t}\right) \\
& +\delta\left[\text { Same Group }_{o d} \times\left(\operatorname{Shock}_{d t}-\operatorname{Shock}_{o t}\right)\right] \\
& +\lambda^{\prime} \mathrm{X}_{o d t}+\alpha_{o}+\alpha_{d}+\alpha_{t}+\epsilon_{o d t} .
\end{aligned}
$$

The variable $\left(\right.$ Shock $_{d t}-$ Shock $_{o t}$ ) denotes the relative change in business conditions between the destination firm $d$ and origin firm $o$.

The $\gamma$ coefficient is the baseline sensitivity of worker flows to the relative shock between firms. We normalize the relative shock by its standard deviation, such that $\gamma$ represents the effect of a one-standard-deviation increase in the relative shock. ${ }^{16}$ The main coefficient of interest is $\delta$, which captures the excess sensitivity of intra-group worker flows to shocks. Under the neoclassical theory, $\delta=0$. In such a world the relative shock to the marginal product of labor is a sufficient statistic for worker flows, which is captured by $\gamma$ alone. If, instead, internal labor markets matter for reallocation, then we should find a statistically significant $\delta$. Internal labor markets can, in principle, dampen $(\delta<0)$ or increase $(\delta>0)$ the response of worker flows to shocks.

We use two alternative measures of shocks to business conditions. First, we use changes in industry-level Tobin's Q, which makes our results more comparable to the existing literature

\footnotetext{
${ }^{15}$ Figure 2 illustrates one possible scenario. Nothing guarantees that in the data the flow between these firms is positive. Also, not all origin firms face shocks, and even if origin firms face shocks, those shocks are not necessarily negative. We allow the data to tell us whether worker flows follow shocks to business conditions or not.

${ }^{16}$ Equation (3.2) uses gross worker flows, and therefore firm pairs with flows to and from each other in the same year are two different observations. The regression with gross flows instead of net flows represents a stricter test because relative shocks imply worker reallocation in only one direction. Firm pairs with flows in both directions represent $12.1 \%$ of the observations in the full sample. The results with net flows are analogous to the results with gross flows.
} 
(Tate and Yang 2015). Second, we use firm-level changes in export and import prices.

\subsubsection{Industry-level Tobin's Q}

Table 5 reports the results for Equation (3.2) using as shocks the percentage change in Tobin's $\mathrm{Q}$ of each firm's industry. The interaction term between the same group dummy and the relative shock is positive but not significant for the sample of all workers (column 1). The effect becomes large and statistically significant at the $5 \%$ level for workers at the top quartile of the withinfirm wage distribution. To interpret the magnitude of the effect, consider an origin group firm that faces a one-standard-deviation relative negative shock. The average destination firm in the same group receives a flow of top-occupation workers that is 2.4 percentage points larger than the average unaffiliated destination firm (column 4). Relative to the standard deviation of top-occupation flows, this result means that there is $12 \%$ more reallocation towards same-group firms than to unaffiliated firms in response to Q shocks $(=0.024 / 0.205)$.

The labor reallocation test has the advantage of allowing us to include firm-pair fixed effects and control for all time-invariant differences between affiliated and unaffiliated pairs. Is is not possible to add pair fixed effects in our baseline regression (3.1), because the business group dummy varies at the pair level and is therefore absorbed by the pair fixed effects. We can include pair fixed effects in the reallocation regression (3.2), because we are interested in identifying the interaction term between group affiliation and the relative shock. By including firm pair fixed effects, we can compare the response to shocks within pairs of affiliated and unaffiliated firms. ${ }^{17}$

Table 6 reports the results of estimating Equation (3.2) with firm-pair fixed effects. This regression is identified on the basis of repeated worker flows between pairs of firms over time. For this reason, the number of observations decreases from around 50,000 to 24,000 (see columns (1) of Tables 5 and 6). The regression confirms the finding that group firms actively use internal labor markets, especially for top-occupation workers. In fact, the coefficients for different segments of the wage distribution are not statistically different than the coefficients reported in the previous table, which includes only origin and destination fixed effects separately. This suggests

\footnotetext{
${ }^{17}$ In principle, we could also control for firm pair fixed effects by relying on time-series variation in businessgroup affiliation status: some group firms leave the business group and become stand-alone firms, and some stand-alone firms join a business group and become group firms. Unfortunately, we only have 10 firms in our sample with worker flows to other firms before and after their transition, which does not give us enough degrees of freedom to implement the test.
} 
that the results are not driven by unobserved heterogeneity between affiliated and unaffiliated pairs.

\subsubsection{Firm-level Trade Shocks}

Our second measure of shocks is based on firm-level trade shocks. There are several shortcomings with shocks to Tobin's Q. First, shocks to Tobin's Q are potentially endogenous to worker flows. Reverse causality is probably the clearest form of endogeneity. A group firm will likely receive top-occupation workers from other group firms, which will in turn increase productivity as we show in Section 5. The increase in productivity will be reflected in the market value of its assets, and hence on Tobin's Q. Second, Tobin's Q shocks are defined at the industry level. This lack of granularity leads to possible endogeneity, because aggregation relies on the endogenous size of firms. Group firms are larger on average, and are more likely to be listed. Hence, group firms have a disproportionate representation in the Tobin's Q of each industry. Finally, Tobin's Q is likely to be a better proxy for changing business conditions in listed firms, while private firms represent the lion's share of our sample. Trade shocks are an attempt to address all of these problems. They are defined at the firm-level; they apply to both listed and private firms; and crucially, they have the advantage of being plausibly exogenous to each firm since Chile is a small and open economy.

Table 7 reports the results of estimating Equation (3.2) using firm-level trade shocks. Trade shocks are only available for firms that engage in international trade, so the number of observations decreases to 20,000 . We do not have enough power to include pair fixed effects because there are too few repeated flows between firms in this sample. Still, the results are very similar to the ones obtained using Tobin's Q: the interaction term between export shocks and group affiliation becomes larger and more significant for top-occupation workers. The average destination firm in the same group receives a flow of top-occupation workers that is 3.2 percentage points larger than the average unaffiliated destination firm (column 4). That is, there is $20 \%$ more reallocation towards same-group firms than to unaffiliated firms in response to export shocks $(=0.032 / 0.160) .{ }^{18}$ To further expand our results, we also consider workers at the top

\footnotetext{
${ }^{18}$ These results are robust to using as left-hand-side variable worker flows normalized by the workers absorbed by the destination firm (see Appendix Table A.6.)
} 
20th and top 10th percentile of the within-firm wage distribution (columns 5 and 6 ). The effect is monotonically increasing as we move along the wage distribution. ${ }^{19}$ Finally, while the effect of export price shocks is statistically significant, the effect of import price shocks is not significant, although it has the expected negative sign. This is consistent with exports being more important than imports for the average firm in our trade sample.

A caveat is that the previous regressions only study the intensive margin of worker flows (i.e., the number of workers moving between two firms), and not the extensive margin (i.e., the likelihood of any worker moving between two firms). Ignoring the extensive margin could bias the estimation of the intensive margin (Wooldridge 2002). Appendix Table A.7 looks at the extensive margin. One practical difficulty with the extensive margin is dimensionality since the number of firm pairs with positive worker flows is small relative to all possible firm pairs (i.e., less than 0.5\%). We re-estimate Equation (3.2) using as dependent variable a dummy variable for firm pairs with a positive worker flow in a given year. We find that the interaction of export price shocks and the same group dummy is positive and significant, meaning that it is more likely that firms in the same group exchange workers between them in response to relative export shocks, but for bottom and top workers alike. Overall, this evidence suggests that there is no bias in our case.

\subsection{Effects on Wages}

In Table 8 we explore the effect on wages, which are the mirror image of labor reallocation. From here onward we focus our tests on firm-level trade shocks, because we believe them to be more plausibly exogenous. We use the same regression specification as in Equation (3.2) with the $(\log )$ change in the wage of the worker that moves between firms as dependent variable. The wages of top-occupation workers that move inside the group increase by 6.6 log points in response to a one-standard-deviation positive relative export shock in the destination firm (column 4). The effects are smaller and not significant for bottom-occupation workers. Our results add to previous wage patterns documented in the literature on internal labor markets of conglomerates. For example, Tate and Yang (2015) find that workers that move away from

\footnotetext{
${ }^{19}$ In Appendix Table A.5, we report the main regression but defining quartiles of workers with the economywide distribution of wages. The results confirm that our mechanism is about top occupations within firms, rather than about workers with high nominal wages.
} 
diversified conglomerates face wage losses.

The wage change of the worker that moves could reflect a positive pass-through of shocks in the destination firm instead of a worker-specific effect. In fact, there is recent evidence that incumbent workers share some of the gains from firms' shocks (see Garin and Silverio 2018, and Kline, Petkova, Williams, and Zidar 2019). To address this concern we subtract from the wage change of the top-occupation mover the wage change of the same type of workers that stay in the destination firm (stayers). The wage gain of top-occupation movers is reduced to 4.8 percentage points (column 5), but it is still significant and economically large. This suggests that the result is associated to the worker that is moving, rather than simply a firm-related effect.

\subsection{Within-Group Worker Flows}

Our results so far compare worker flows between affiliated and unaffiliated firms. As explained above, affiliated firm pairs could be different for reasons other than common ownership. All of our tests try to control for these differences from various angles. A perhaps simpler way to address this issue is to restrict our attention to flows within groups. Following the logic of Stein (1997), we test whether the owner of a business group with two firms $A$ and $B$ channels more scarce resources towards firm $B$ if the appeal of investing in firm $B$ suddenly increases. Employment in firm $A$ could decline even if it is a positive net-present-value investment at the margin. We estimate the following within-group regression:

$$
\begin{aligned}
\text { Worker Flow }_{\text {odt }}^{\text {SameGroup }} & =\beta\left(\text { Shock }_{d t}-\text { Shock }_{o t}\right)+\lambda^{\prime} \mathrm{X}_{o d t} \\
& +\alpha_{o}+\alpha_{d}+\alpha_{t}+\epsilon_{\text {odt }}
\end{aligned}
$$

where firms $o$ and $d$ belong to the same business group. We report the results in Table 9 . We find that a business group firm sends more workers to the affiliated firms facing the most favorable shocks. As before, the effect is increasing in the within-firm wage distribution and is statistically significant at the $5 \%$ level for top-occupation workers $(3.6 \%$ in response to export shocks in column 4). The magnitude of the effects and statistical significance are comparable to those reported in Table 7 despite the fact that the number of observations is much smaller. 


\section{Why do Groups use Internal Labor Markets?}

In the previous section we show that business groups actively use internal labor markets, especially so for top-occupation workers. In this section we explore the rationale behind internal labor mobility. We study the standard frictions that could make internal labor markets more convenient than external labor markets: transaction costs, diversification, imperfect insurance, and asymmetric information. We provide some evidence against each of these hypotheses. However, because our proxies are imprecise, we cannot rule out any of these frictions. Instead, we provide evidence consistent with a new hypothesis developed in this paper, which we label the "intangible inputs" hypothesis.

\subsection{Transaction Costs}

A firm has to pay firing costs (e.g., severance payments) and hiring costs (e.g., head-hunting services, moving expenses, training) when dealing with workers from the external labor market. Hiring costs alone can be as high as six months of wages (Tate and Yang, 2015). A business group firm can save on some of these transaction costs. For example, when hiring from an affiliated firm labor laws usually exempt moves from severance payments (Belenzon and Tsolmon, 2016). Transaction costs are typically proportional to wages, which could in principle explain the stronger advantage of internal labor markets for top-occupation workers. At the same time, some transactions costs are top-coded, which reduces their impact on the firm's bottom line. These costs can also be small relative to the productivity gains of reallocating top-occupation workers.

In what follows we use proxies for particular transaction costs. For instance, because severance payments are increasing in the tenure of the worker being fired, the transaction costs hypothesis predicts that internal labor mobility should be stronger for workers with longer tenure. In order to test this prediction we re-estimate Equation (3.2) adding a triple interaction term between the relative export shock, the same-group dummy, and the tenure of the worker in the origin firm or in the group. Table 10 is focused on top-workers. Columns 2 and 3 show that the triple interactions are not statistically significant, indicating that internal labor mobility is not stronger among workers with longer tenure. 
We use geographical distance (geodesic) between the origin and destination firm as a proxy for search costs. Business groups might have an advantage in bridging between distant labor markets. Column 4 of Table 10 shows that the triple interaction with distance is not significant. Finally, older worker can imply higher training and moving expenses. However, column 5 shows that the triple interaction term with age is negative, meaning that internal mobility is not stronger for older workers.

\subsection{Diversification}

There are at least two hypothesis that relate internal labor markets with the degree of diversification of the business group. First, if labor and capital are complements, then internal labor mobility can reflect a friction in the capital market rather than in the labor market. For instance, imperfect capital markets prevent investors from achieving their desired degree of diversification, but business groups can allow their owners to hold more diversified portfolios. In turn, better diversification encourages more risk-taking and faster reallocation in response to shocks (Faccio, Marchica, and Mura 2011). Second, internal labor markets can smooth the transfer of human capital between industries that require similar skills (Tate and Yang 2019). Business group would then diversify across industries, at least in part, to take advantage of the benefits of internal labor reallocation.

In Table 10 we explore the effects of diversification using three proxies for group diversification: the number of different industrial sectors covered by the business group (column 6), the degree of integration between those industries as measured by the input-output matrix for the Chilean economy (column 7), and the dispersion of employment between the firms in the business group (column 8). This last proxy can capture the presence of startups, different lines of business within the same industry, or other types of innovative or risk-taking behavior. We find that the triple interaction terms with all these proxies are not significant, suggesting a limited connection between diversification and the response of internal labor flows.

\subsection{Imperfect Insurance}

Business groups can provide implicit unemployment insurance to workers by offering greater job stability within the group in exchange for lower wages. Cestone, Fumagalli, Kramarz, and Pica 
(2017) focus on this hypothesis to explain labor mobility within French business groups. The insurance hypothesis is not consistent with three of our results.

First, perfect insurance implies no pass-through of shocks to wages (Guiso, Pistaferri, and Schivardi, 2005), something that we can reject with the results shown in Table 8. Second, insurance should be more relevant for poor workers because they have less access to consumption smoothing in financial markets (Blundell, Pistaferri, and Preston, 2008). Instead, our findings are concentrated on top-occupation workers. Third, we explore differences in our results according to the nature of the shocks. In particular, we look at "push" shocks, which we define as negative shocks for the origin firm. The response to push shocks should represent the lion's share of our results if insurance is the underlying mechanism. This is partly the reason why the insurance literature is focused on plant closures and mass layoffs. We find, instead, that the triple interaction with the push dummy is negative, implying that there is less, and not more, reallocation in response to push shocks (column 9 of Table 10). ${ }^{20}$

\subsection{Asymmetric Information}

Labor markets can be affected by asymmetric information because employers learn about the true productivity of the worker only after hiring. In such a world, a business group considering a within-group move for a worker has an advantage over outside employers because it already knows the true productivity of the worker. In this section we test one specific channel related to asymmetric information, namely promotions. When a worker moves from one firm to another, the move itself conveys information to other employers. As shown by Waldman (1984), job promotions imply a wage increase because the employer has to make up for the signalling effect of revealing the worker's high productivity to the market. This could explain the wage gains of the workers that move within the group.

We do not have direct data on job categories or occupations, but we proxy for promotions with the change of ranking in the within-firm wage distribution of the worker that moves. For example, a worker that is the third highest-paid worker in the origin firm and moves to be the second highest-paid worker in the destination firm would have a change of ranking equal to

\footnotetext{
${ }^{20}$ Table A.8 in the appendix shows heterogeneity of our results in other dimensions, for example, whether shocks are large or small, or the intensity of shocks in different industries (e.g., manufacturing).
} 
one. Table 11 reports the results of re-estimating Equation (3.2) using the wage rank change as dependent variable. We find that the coefficient on the interaction term of the same group dummy and export shocks is positive and significant (column 4) which suggests that withingroup movements are indeed related to promotions. Interestingly, the effect of import shocks on the wage ranking of top-occupation workers is negative, significant, and almost as large in magnitude as the positive effect of export price shocks (column 4). Given downward rigidity in nominal wages, the wage ranking can be a better proxy for reallocation in response to negative shocks.

The effects on wage ranking of both export and import shocks are not significant among workers at the bottom or the middle of the wage distribution. This speaks against the asymmetric information hypothesis because the signalling effect of promotions should be stronger in workers with lower wages (DeVaro and Waldman, 2012). This should happen because topoccupation workers have other means to signal productivity (e.g., education), so the signalling effect of promotions should be smaller among them.

\subsection{Intangible Inputs}

We now propose a new hypothesis, which we label the "intangible inputs" hypothesis, to explain why business groups take advantage of internal labor markets. Our hypothesis builds on the recent work of Atalay, Hortaçsu, and Syverson (2014) and Ding, Fort, Redding, and Schott (2019). Intangible inputs such as management practices, knowledge, know-how, organizational culture, and others are key factors of production. The key friction that affects the transfer of intangibles between firms is imperfect contractibility. ${ }^{21}$ Intangible inputs are hard to quantify, and they are often embedded in the human capital of workers (Eisfeldt and Papanikolaou 2013), so transferring intangible inputs implies transferring workers and particularly top-workers. Common ownership, which is a feature of conglomerates and business groups, can provide an environment that facilitates the transfer of intangible inputs. We explore two variations of the intangibles input hypotheses -the specificity hypothesis and the hierarchy hypothesis.

Along the lines of Grossman and Hart (1986), common ownership allows for the accumula-

\footnotetext{
${ }^{21}$ This can explain observed persistent differences in intangibles across firms (see Bloom and Van Reenen 2007 on cross-firm differences in managerial practices)
} 
tion and transfer of intangible inputs in a simpler way than market relationships because of control rights over productive assets. Top-occupation workers make non-contractible relationshipspecific investments to acquire intangible inputs, such as management practices. For instance, workers put effort in training to adjust to the new organization or in earning the trust of the controlling shareholder. A worker who has invested in these intangibles is more valuable to the firm than the average worker from the external market. Business groups have an advantage over stand-alone firms because, by virtue of the control rights over multiple firms, they reduce the specificity of the investment. Simply put, intangibles can be used over many more assets. A business group controls firms in multiple sectors, firms in different stages of their life-cycle, and firms in different markets or countries. Hence, it is reasonable to expect that opportunities for managers to apply those intangibles will indeed arise. By reducing specificity, business groups provide more incentives for workers to invest in intangibles in the first place, which overall produces better managers. ${ }^{22}$

A key prediction of the specificity hypothesis is that relationship-specific investments lead to hold up or the threat of expropriation. The controlling shareholder favors the use of internal workers when facing a profitability shock, because they are more valuable than outside workers. The internal worker knows this, and in renegotiating the wage in the new position, she can extract some of the rents that the shock produces. The fact that wages of top-occupation workers increase when they move between firms of the same group supports this hypothesis (Table 8). The wage gain gives ex-ante incentives to acquire intangibles. If the controlling shareholder has full bargaining power, then no worker would invest in acquiring intangibles.

An aspect of business groups that the specificity hypothesis does not capture is their hierarchical structure. In most groups control is exercised in steps or layers (see, for example, Figure 1). The headquarter or holding company at the top of the pyramidal structure decides major strategic moves (e.g., mergers and acquisitions) while the implementation of the overall strategy and minor decisions are taken in firms below in the hierarchy (i.e., managing by exception). According to Garicano and Rossi-Hansberg (2015), the role of such a hierarchy is to allow workers to better use their knowledge -an intangible input- by delegating and coordinating with other

\footnotetext{
${ }^{22}$ Non-contractibility implies that monetary incentives are often insufficient to insure that these investments are made (Burkart, Gromb, and Panunzi, 1997).
} 
workers. $^{23}$ In short, the hierarchy allows workers to leverage their knowledge. By providing a large set of assets and production problems across which to apply knowledge, the hierarchies that characterize business groups lever more on the knowledge of their managers.

In Table 12 we show evidence consistent with the hierarchy hypothesis. In column 2, we find that internal labor mobility for top-occupation workers is more pronounced when the firm that sends the worker controls the firm that receives the worker; that is, when the top-occupation worker is being transferred from above in the hierarchical structure. This suggests that the worker is a better manager because there is positive sorting in hierarchies (Garicano and RossiHansberg 2006). In column 3, we relate our results to the pyramidality of the control structure of the group. In a more pyramidal group, there are more links between intermediate firms, instead of firms depending directly from the parent company. ${ }^{24}$ We find that internal labor mobility of top-occupation workers is more pronounced in these more complex hierarchies (column 3).

The downside of the hierarchy hypothesis for our setup is that there is no explicit role for ownership, or rather, it assumes that all production happens in an environment of full control rights (i.e., within a firm). There is no difference between having a large hierarchy across firms in a business group and a similarly large hierarchy within a firm. ${ }^{25}$ In addition, it is not clear if the hierarchy hypothesis can account for the wage dynamics of movers in our setup. Under this hypothesis, wage changes are explained by changes in the structure of the hierarchy (e.g., adding layers to the hierarchy as in Caliendo, Monte, and Rossi-Hansberg 2015) and not by moving within the structure.

\section{$5 \quad$ Firm-level Effects of Internal Labor Mobility}

Finally, we study the effect of internal labor market mobility on firm-level outcomes. We focus on wages and employment because most of the firms in our sample are private and, hence, we do not have access to other financial information. We start with reduced-form evidence. Then we perform a tighter comparison of firms that receive a top-worker from within the group and

\footnotetext{
${ }^{23}$ See also Hart and Moore (2005) for a related model of hierarchies.

${ }^{24}$ We measure group pyramidality as the difference between the control rights and the cash-flow rights of the controlling shareholder in the average firm of the group (Khanna and Yafeh, 2007). In a stand-alone firm this measure is zero. This measure converges to one as the pyramid gets infinitely large.

${ }^{25}$ For a model of business groups as knowledge-based hierarchies, see Altomonte, Ottaviano, and Rungi (2018).
} 
other firms. The evidence reported in this section is only suggestive because we cannot rule out other mechanisms working simultaneously with internal labor markets.

\section{$5.1 \quad$ Reduced-form Evidence}

We first study whether business-group firms respond to export shocks differently than standalone firms. We run firm-level regressions of wage and employment growth on lagged export shocks, the interaction between the shocks and a business-group indicator, and firm and year fixed effects. We report the results in Table 13. We find that export shocks lead to higher wage growth in group firms with a lag of one or two years, and this effect holds for both topand bottom-occupation workers (columns 2 through 4). At the same time, employment growth in group firms responds less to export price shocks than stand-alone firms (column 5). Higher wage growth and lower employment growth suggest increasing productivity in group firms as a response to export shocks. In line with our results in column 5, recent cross-country evidence shows that employment is less responsive to aggregate shocks in business-group firms than in stand-alone firms (Faccio and O'Brien, 2017). Our findings suggest that internal labor markets are one reason behind the differential response of group firms to shocks.

\subsection{Synthetic Control Comparisons}

Next, we study whether the arrival of a new worker from within the business group creates value for the destination firm. If the new worker is endowed with more intangibles, and if she is in a top position, she can potentially have an impact on the entire firm. As shown by Bloom, Eifert, Mahajan, McKenzie, and Roberts (2013), better managerial practices can have large effects on firm-level productivity.

We implement event studies following the synthetic control strategy of Abadie and Gardeazabal (2003), and Abadie, Diamond, and Hainmueller (2010). We contrast the productivity gains of treated and control firms, where firm productivity is proxied by average wage. We first define treated firms as destination firms in a group that receive a top-occupation worker from within the group. The synthetic control firms are destination firms (stand-alone or in a group) that receive a top-occupation worker from an unaffiliated firm. In order to build our synthetic controls we use a window of three years before receiving a top-occupation worker. The weights in 
the synthetic controls are defined by a minimum distance approach based on firm-level trade shocks, industry, employment level, and dummies for being an exporter-importer. Both treated and control firms receive shocks in our experiment.

Figure 3 reports the results. Treated firms in Panel A show an increase in wages, while control firms show a slight decrease in wages. The difference between treated and control firms is $12.3 \%$ in the period after the arrival of the top worker (see Appendix Table A.9). The effect is significant at the $1 \%$ level. As we previously showed, the wage of the top-occupation worker increases after she moves between firms of the same group. This could mechanically explain the result that the average wage of a group firm increases after receiving a top-occupation worker. To address this issue, in Panel $\mathrm{B}$ we compute the average wage of the destination firm after excluding the top-occupation worker that arrived. Although smaller, the difference of $9.4 \%$ remains highly significant (see Appendix Table A.9). This is consistent with the idea that the movement of the top-occupation worker has a positive spillover on productivity of the other workers (Jarosch, Oberfield, and Rossi-Hansberg 2018).

In Panel $\mathrm{C}$ we report the effects on wages at the origin firm. The treated firms are group firms that send a top-occupation worker to other group firms, and the control firms are group firms that also send a top-occupation worker, but to unaffiliated firms. We find that the average change in the wage of origin firms is much smaller, and the difference between treated and control firms is not statistically significant.

In Panels A and B of Appendix Figure A.2, we repeat the previous experiments, but using as control firms those that receive any top-occupation worker, not necessarily one coming from a group. This increases the set of possible controls. The differences are still economically relevant (2.9\% and $3.6 \%$ respectively in Panels A and B), and statistically significant. Finally, in Panel C of Appendix Figure A.2 we study group firms that send top-occupation workers to any other firm, and we use as control firms those stand-alone firms that also send a top-occupation worker. Again, the difference between treated and control firms is negligible.

In sum, the average wage increases when a group firm receives a top-occupation worker from within the group, and it remains roughly unchanged when a group firm sends a top-occupation worker. Because the overall wage of the business group is a weighted average of the wages of the different group firms, this evidence suggests that internal labor reallocation increases overall 
group productivity.

\section{Conclusions}

Business groups -legally independent firms controlled by the same ultimate owner- are common corporate structures around the world. There are several reasons that can explain the existence of these complex ownership structures. In this paper we focus on the use of internal labor markets. Business-group firms, unlike stand-alone firms, have the option of moving workers within the group, which could be cheaper than relying on external labor markets. Using a matched employer-employee dataset for Chile we provide novel micro evidence of strong labor mobility inside business groups. Worker flows between group firms are significantly more prevalent than between unaffiliated firms. On average, a group firm sends five times more workers to a firm in the same group than to an unaffiliated firm. The effect is stronger for top-occupation workers.

As a test for the logic that underlies internal labor reallocation, we study how the response of worker flows to changing business conditions depends on business group affiliation. We proxy for business conditions using industry-level changes in Tobin's $\mathrm{Q}$ and firm-level changes in export (and import) prices, which is a novel approach to the finance literature. Firm-level trade shocks have the advantage of being plausibly exogenous to worker flows since Chile is small and open economy. We find that in response to both types of shocks group firms send more workers to affiliated firms than to unaffiliated firms, especially top-occupation workers. The wages of those workers increase as they move within the group. The response to business conditions holds when we restrict the sample to worker flows solely within business groups.

Regarding the potential drivers behind internal labor mobility our results are consistent with a new hypothesis that we label the "intangible inputs" hypothesis. According to this hypothesis, common ownership facilitates the transfer of intangible inputs (e.g., management practices, knowledge, know-how, organizational culture) between group firms. The ease to transfer intangibles between firms, embedded in top-occupation workers, is a novel advantage of business groups that we highlight in this paper.

Finally, we look at the effect on average wages, our proxy for productivity, on the firm receiving top-occupation workers and on the firm sending those workers. We find a positive 
effect on the destination firm and no effect on the origin firm, suggesting that reallocation increases group productivity. Together with the fact that group firms send workers towards the affiliated firms with improved business conditions, the findings in our paper are consistent with the idea that internal labor mobility adds value by reallocating scarce resources across group firms. 


\section{References}

Abadie, Alberto, Alexis Diamond, and Jens Hainmueller, 2010, Synthetic control methods for comparative case studies: Estimating the effect of California's tobacco control program, Journal of the American Statistical Association 105, 493-505. 5.2

Abadie, Alberto, and Javier Gardeazabal, 2003, The economic costs of conflict: A case study of the Basque country, American Economic Review 93, 113-132. 5.2

Almeida, Heitor, Chang Soo Kim, and Hwanki Brian Kim, 2015, Internal capital markets in business groups: Evidence from the Asian financial crisis, Journal of Finance 70, 2539-2586. 1

Altomonte, Carlo, Gianmarco Ottaviano, and Armando Rungi, 2018, Business groups as knowledge-based hierarchies of firms, Working paper. 25

Atalay, Enghin, Ali Hortaçsu, and Chad Syverson, 2014, Vertical integration and input flows, American Economic Review 104, 1120-1148. 1, 4.5

Autor, David H., David Dorn, and Gordon H. Hanson, 2013, The China syndrome: Local labor market effects of import competition in the United States, American Economic Review 103, 2121-68. 2, 2.3

Bartik, Timothy J, 1991, Who benefits from state and local economic development policies?, . 2.3

Belenzon, Sharon, and Ulya Tsolmon, 2016, Market frictions and the competitive advantage of internal labor markets, Strategic Management Journal 37, 1280-1303. 1, 4.1

Bernard, Andrew B., Jonathan Eaton, J. Bradford Jensen, and Samuel Kortum, 2003, Plants and productivity in international trade, American Economic Review 93, 1268-1290. 2.4

Blanchard, Olivier Jean, and Lawrence F Katz, 1992, Regional evolutions, Brookings Papers on Economic Activity 1992, 1-75. 2.3

Bloom, Nicholas, Ben Eifert, Aprahit Mahajan, David McKenzie, and John Roberts, 2013, Does management matter? Evidence from India, Quarterly Journal of Economics 128, 1-51. 5.2

Bloom, Nicholas, and John Van Reenen, 2007, Measuring and explaining management practices across firms and countries, Quarterly Journal of Economics 122, 1351-1408. 21

Blundell, Richard, Luigi Pistaferri, and Ian Preston, 2008, Consumption inequality and partial insurance, American Economic Review 98, 1887-1921. 4.3

Boutin, Xavier, Giacinta Cestone, Chiara Fumagalli, Giovanni Pica, and Nicolas SerranoVelarde, 2013, The deep-pocket effect of internal capital markets, Journal of Financial Economics 109, 122-145. 1

Buchuk, David, Borja Larrain, Francisco Munoz, and Francisco Urzúa, 2014, The internal capital markets of business groups: Evidence from intra-group loans, Journal of Financial Economics $112,190-212.1,2.2$

Buchuk, David, Borja Larrain, Mounu Prem, and Francisco Urzúa, 2019, How do internal capital markets work? Evidence from the great recession, Review of Finance. 1 
Burkart, Mike, Denis Gromb, and Fausto Panunzi, 1997, Large shareholders, monitoring, and the value of the firm, Quarterly Journal of Economics 112, 693-728. 22

Caliendo, Lorenzo, Ferdinando Monte, and Esteban Rossi-Hansberg, 2015, The anatomy of French production hierarchies, Journal of Political Economy 123, 809-852. 4.5

Card, David, Jorg Heining, and Patrick Kline, 2013, Workplace heterogeneity and the rise of west German wage inequality, Quarterly Journal of Economics 128, 967-1015. 2.1, A.1

Cestone, Giacinta, Chiara Fumagalli, Francis Kramarz, and Giovanni Pica, 2017, Insurance between firms: The role of internal labor markets, Working paper. 1, 2.4, 4.3

Davis, Steven, and Till von Wachter, 2011, Recessions and the costs of job loss, Brookings Papers on Economic Activity 43, 1-72. 8

DeVaro, Jed, and Michael Waldman, 2012, The signaling role of promotions: Further theory and empirical evidence, Journal of Labor Economics 30, 91-147. 4.4

Ding, Xiang, Teresa Fort, Stephen Redding, and Peter Schott, 2019, Structural change within versus across firms: Evidence from the United States, Working Paper Harvard University. 1, 4.5

Donelli, Marcelo, Borja Larrain, and Francisco Urzúa, 2013, Ownership dynamics with large shareholders: An empirical analysis, Journal of Financial and Quantitative Analysis 48, 579609. 2.2

Eisfeldt, Andrea, and Dimitris Papanikolaou, 2013, Organization capital and the cross-section of expected returns, Journal of Finance 68, 1365-1406. 4.5

Faccio, Mara, Maria-Teresa Marchica, and Roberto Mura, 2011, Large shareholder diversification and corporate risk-taking, Review of Financial Studies 24, 3601-3641. 4.2

Faccio, Mara, and William O'Brien, 2017, Business groups and employment, Working paper. 3, $1,5.1$

Garicano, Luis, and Esteban Rossi-Hansberg, 2006, Organization and inequality in a knowledge economy, Quarterly Journal of Economics 121, 1383-1435. 4.5

, 2015, Knowledge-based hierarchies: Using organizations to understand the economy, Annual Review of Economics 7, 1-30. 4.5

Garin, Andrew, and Filipe Silverio, 2018, How responsive are wages to demand within the firm? Evidence from idiosyncratic export demand shocks, Working paper. 1, 3.3

Giroud, Xavier, and Holger Mueller, 2015, Capital and labor reallocation within firms, Journal of Finance 70, 1767-1804. 1

Gopalan, Radha, Vikram Nanda, and Amit Seru, 2007, Affiliated firms and financial support: Evidence from Indian business groups, Journal of Financial Economics 86, 759-795. 1

Grossman, Sanford J., and Oliver D. Hart, 1986, The costs and benefits of ownership: A theory of vertical and lateral integration, Journal of Political Economy 94, 691-719. 4.5 
Guiso, Luigi, Luigi Pistaferri, and Fabiano Schivardi, 2005, Insurance within the firm, Journal of Political Economy 113, 1054-1087. 4.3

Hart, Oliver D., 2001, Financial contracting, Journal of Economic Literature 39, 1079-1100. 1

— and John Moore, 2005, On the design of hierarchies: Coordination versus specialization, Journal of Political Economy 113, 675-702. 23

Hummels, David, Rasmus Jørgensen, Jakob Munch, and Chong Xiang, 2014, The wage effects of offshoring: Evidence from Danish matched worker-firm data, American Economic Review 104, 1597-1629. 2, 2.3

Jacobson, Louis S., Robert J. LaLonde, and Daniel G. Sullivan, 1993, Earnings losses of displaced workers, The American Economic Review 83, 685-709. 8

Jarosch, Gregor, Ezra Oberfield, and Esteban Rossi-Hansberg, 2018, Learning from coworkers, Working paper, Princeton University. 5.2

Khanna, Tarun, and Yishay Yafeh, 2007, Business groups in emerging markets: Paragons or parasites?, Journal of Economic Literature 45, 331-372. 1, 24

Kline, Patrick, Neviana Petkova, Heidi Williams, and Owen Zidar, 2019, Who profits from patents? Rent-sharing at innovative firms, Quarterly Journal of Economics 134, 1343-1404. $1,3.3$

Melitz, Marc J, 2003, The impact of trade on intra-industry reallocations and aggregate industry productivity, Econometrica 71, 1695-1725. 2.4

Modigliani, Franco, and Merton H Miller, 1958, The cost of capital, corporation finance and the theory of investment, American Economic Review 48, 261-297. 3.1

Morck, Randall, Daniel Wolfenzon, and Bernard Yeung, 2005, Corporate governance, economic entrenchment, and growth, Journal of Economic Literature 43, 655-720. 1

Silva, Rui, 2017, Internal labor markets, wage convergence and investment, Working Paper. 1

Song, Jae, David J. Price, Fatih Guvenen, Nicholas Bloom, and Till Von Wachter, 2015, Firming up inequality, Discussion paper, National Bureau of Economic Research. A.1

Stein, Jeremy C., 1997, Internal capital markets and the competition for corporate resources, Journal of Finance 52, 111-133. 1, 3.4

Tate, Geoffrey, and Liu Yang, 2015, The bright side of corporate diversification: Evidence from internal labor markets, Review of Financial Studies 28, 2203-2249. 1, 2.3, 3.2, 3.3, 4.1

— , 2019, The human factor in acquisitions: Cross-industry labor mobility and corporate diversification, pp. -.4 .2$

Waldman, Michael, 1984, Job assignments, signalling, and efficiency, Rand Journal of Economics 15, 255-267. 4.4

Wooldridge, Jeffrey, 2002, Econometric Analysis of Cross Section and Panel Data (The MIT Press: Cambridge, MA). 3.2.2 


\section{Appendix}

\section{A.1 Data Appendix}

This appendix describes in detail the datasets used in the paper and the cleaning procedures and merging procedures used.

Limitations of Unemployment Insurance Dataset. Wage records are subject to three important limitations. First, they include only workers who have formal contracts with employers. According to standard estimates of the main employment survey in Chile carried out by the Institute of National Statistics, around $83 \%$ of dependent employment is formal in Chile, one of the highest in the region. Second, they include only workers who signed their contracts after 2002. Thus, workers with formal contracts that either (i) started working after 2002, (ii) changed formal jobs after 2002 and/or (iii) renegotiated any contract characteristic after 2002, should be in the dataset. Since 2002, the coverage of the dataset has been increasing. In fact, aggregate employment that appears in the unemployment insurance (UI) dataset in 2015, i.e., around 4.6 million, is less than the population that contributes to pension funds, 5.1 million, which is not affected by the constraints of the dataset. Nevertheless, workers contributing to pension funds include public workers, which are around 600,000. Thus, by 2015, aggregate employment of the dataset is approximately the same as the one reported by pension funds administrators. Third, wages are top-coded at a certain threshold. Around $4 \%$ of workers were top-coded in their main jobs in 2015 , which represents around $20 \%$ of firms' aggregate wage expenditures. ${ }^{26}$

Cleaning Process of Unemployment Insurance Dataset. We implement a set of cleaning filters to the dataset that are standard in the literature (Song, Price, Guvenen, Bloom, and Von Wachter 2015; Card, Heining, and Kline 2013). First, we drop firms that have less than 5 workers. These represent around $2 / 3$ of the total number of firms and represent around $8 \%$ of total employment in 2015. We drop these firms because the identification of a firm in the dataset is done through tax IDs. Thus, there might be concerns that tax IDs with few workers might not be firms but, e.g., shell corporations for tax purposes. This decision also helps to make more meaningful the statistics of within-firm distribution of workers and it follows the restrictions applied in matched employer-employee datasets. Second, we focus on spells at the highest-paying jobs for each individual in each year. This implies dropping around $17 \%$ of total job spells per year. Regarding workers that have several jobs, the income of their main jobs represents around $90 \%$ of their total labor income across jobs in 2015 . Third, we exclude workers that have a weak labor attachment. That is, we exclude workers that earn less than a quarter of the annual equivalent of the minimum wage. These workers represent around $15 \%$ of employment and around 1\% of firms' aggregate wage expenditures in 2015. Given these restrictions, we end up with a dataset of around 100,000 employers and 4.6 million workers.

Business Groups Dataset Limitations. Two caveats about the ownership data are in order. First, our business group data excludes financial firms (commercial banks, mutual fund companies, pension fund administrators, etc.). This is not a big omission for our purposes because ties between business groups and banks have been limited by regulation since the aftermath of the debt crisis in the 1980s. Second, although we are able to identify the private firms that belong to each group, we do not know the direct ownership stake between pairs of private firms in the group. For example, if $\mathrm{X}$ is a listed firm, and $\mathrm{Y}$ and $\mathrm{Z}$ are private firms that consolidate with

\footnotetext{
${ }^{26}$ This number represents a lower bound due to the fact that wages are censored for top-coded workers.
} 
$\mathrm{X}$, then we know that $\mathrm{X}, \mathrm{Y}$, and $\mathrm{Z}$ belong to the same group. We also know the stake between $\mathrm{X}$ and $\mathrm{Y}$. However, we do not know the stake between $\mathrm{Y}$ and $\mathrm{Z}$.

Merge of the Labor Dataset with the Business Group Dataset. As with the employeremployee dataset, firms in the business groups data are identified with unique tax IDs. We use these unique identifiers to merge both datasets. From the business group dataset, around $45 \%$ of firms are on average across years in the employer-employee dataset. From the aforementioned cleaned employer-employee dataset, around $0.3 \%$ of firms across years are in the business group dataset. These firms represent on average about $3 \%$ and $5 \%$ of aggregate employment and wage bill, respectively. At the same time, these firms represent close to $80 \%$ of the stock market capitalization of the Chilean market, and their total revenue over GDP is almost $60 \%$.

COMTRADE dataset. This dataset is organized and cleaned by the Centre d'Etudes Prospectives et d'Informations Internationales (CEPII, for its acronym in French). CEPII organizes COMTRADE's database into BACI, which is a cleaned version of COMTRADE's database. This dataset, identifies the value and quantity for each 6-digit HS product and country that is traded globally. This dataset is merged to the firm-level international trade dataset using unique HS codes and country IDs.

Merge of the Customs Dataset with the Labor Dataset. Once the international price shocks are created at the firm level, the international trade dataset is merged at the firm level with the unemployment insurance and group data using firms' unique tax IDs. ${ }^{27}$ From the trade dataset, around $45 \%$ of firms that either export or import are merged with the UI dataset on average across years. These firms that are merged account for around $98 \%$ and $95 \%$ of export and import flows, respectively. From the cleaned UI dataset, around $4 \%$ and $15 \%$ of firms export and import, respectively. Among firms that are merged, importers account for around $38 \%$ and $50 \%$ of employment and aggregate wage bill, respectively, whereas exporters account for $15 \%$ and $25 \%$, respectively. Among firms that appear in both the UI and trade dataset, $73 \%$ are only importers, $6 \%$ are only exporters and $21 \%$ do both. Firms that do both activities account for $97 \%$ and $72 \%$ of aggregate exports and imports, respectively.

\footnotetext{
${ }^{27}$ It is important to note that, due to confidentiality restrictions, this merge is implemented by the Secretary of Labor, which manages the UI dataset, and has an agreement with Customs to use the International Trade data. The authors in this paper only have access to the merged dataset once all tax IDs are erased and replaced with fake IDs. This guarantees anonymity and the confidentiality of the dataset.
} 
Figure 1: Example of Business Group Ownership Structure: Antarchile

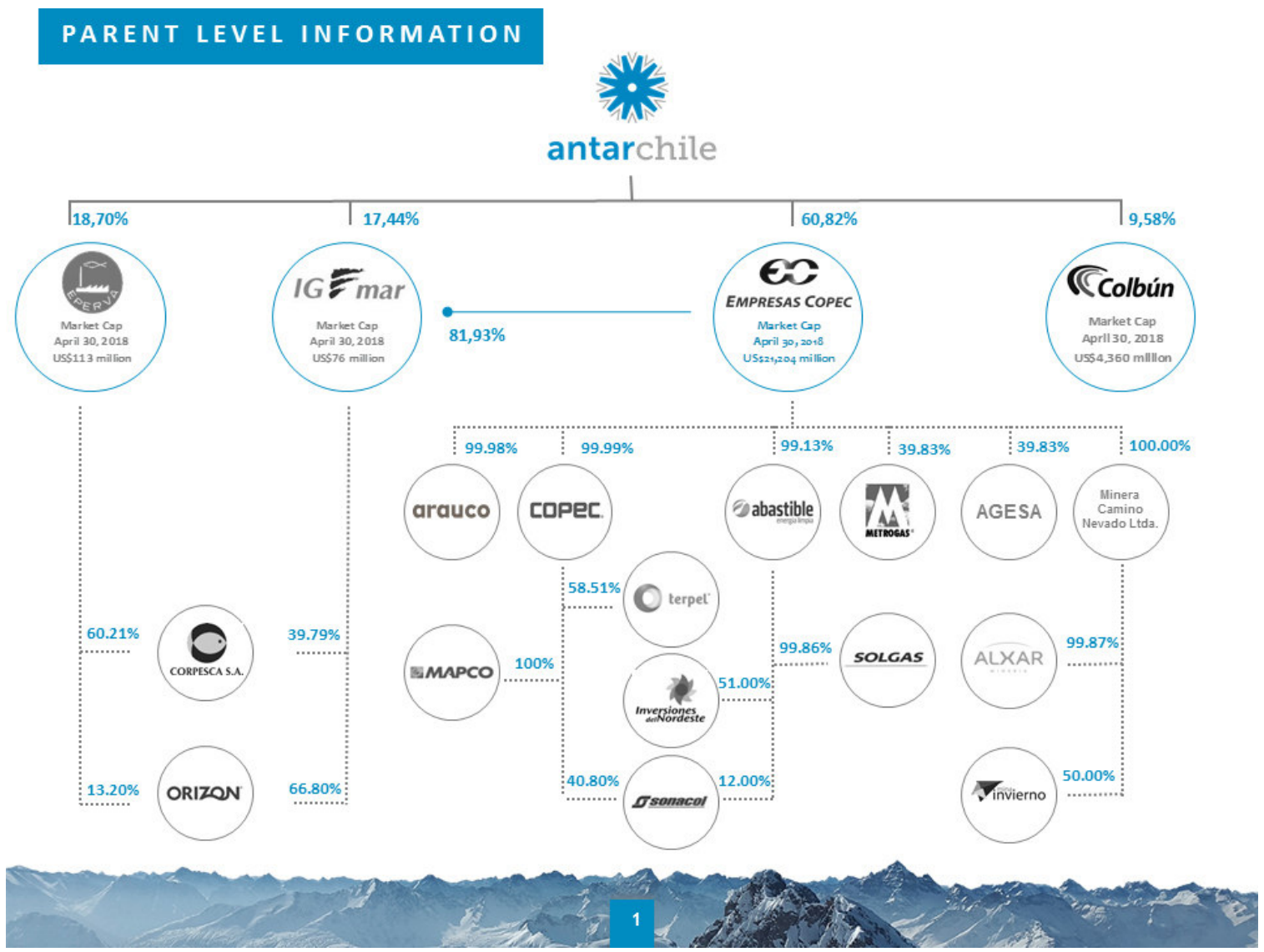

Notes: This figure presents the ownership structure of Antarchile, one of the largest business groups in Chile and controlled by the Angelini family. 
Figure 2: Illustration of Internal Labor Reallocation and Changing Business Conditions

\section{Origin Firm Destination Firm}

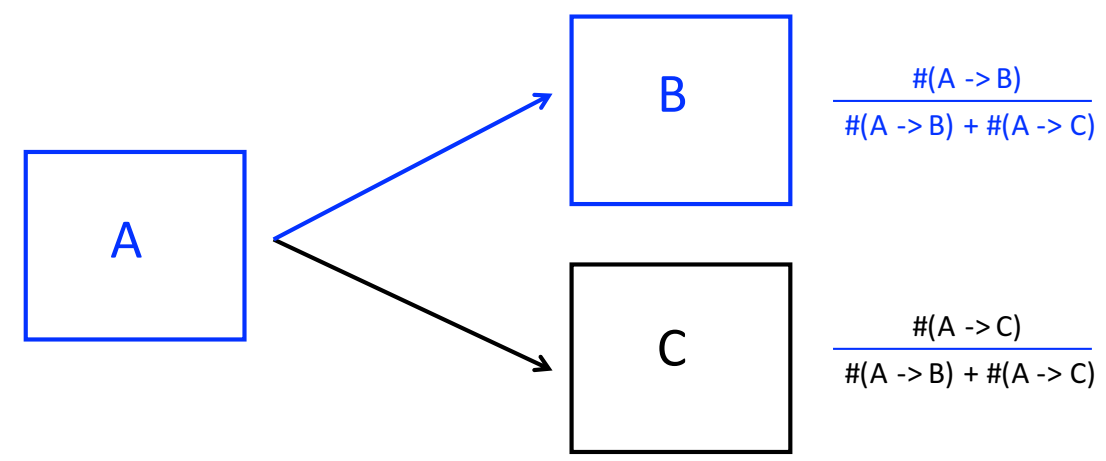

\section{$A$ and $B$ belong to the same business group}

Notes: This diagram illustrates the identification strategy used in the paper (see Section3.2). Firms $A$ and $B$ belong to the same business group, while firms $A$ and $C$ are unaffiliated. Assume firm $A$ faces a negative shock and firms $B$ and $C$ face both the same positive shock. Then we compare $\frac{\#(A \rightarrow B)}{\#(A \rightarrow B)+\#(A \rightarrow C)}$ to $\frac{\#(A \rightarrow C)}{\#(A \rightarrow B)+\#(A \rightarrow C)}$, where $\#(A \rightarrow B)$ denotes the number of workers moving from firm $A$ to firm $B$ and $\#(A \rightarrow C)$ denotes the number of workers moving from firm A to firm $\mathrm{C}$. 
Figure 3: Impact of Receiving and Sending a Top-Occupation Worker

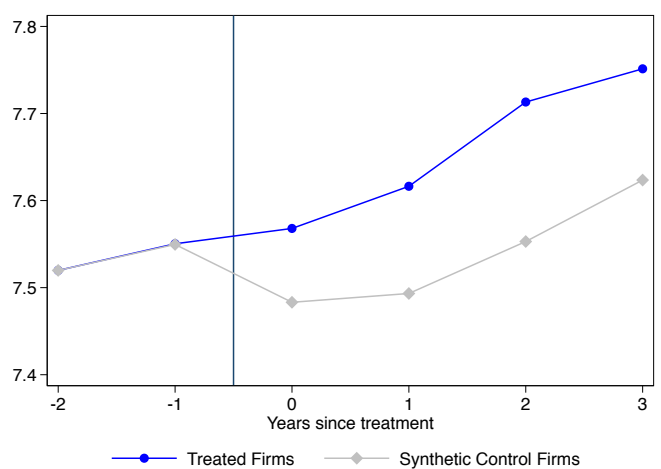

A. Destination Firm: Average wage

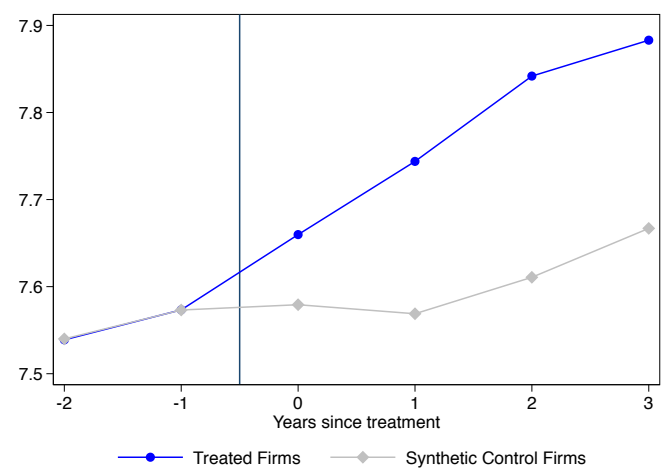

B. Destination Firm's Stayers: Average wage

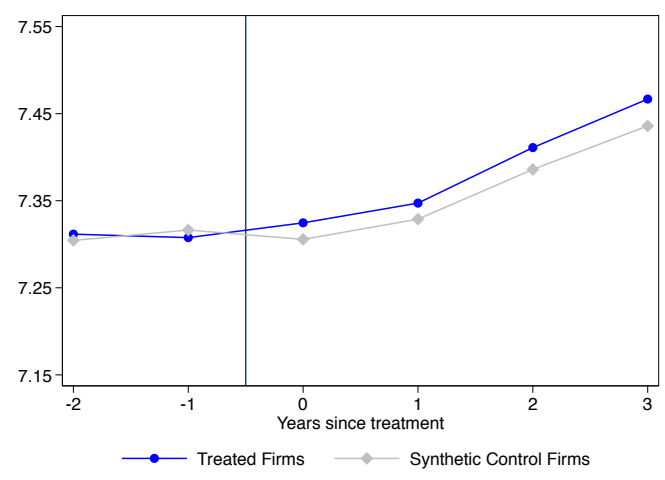

C. Origin Firm: Average wage

Notes: This figure shows the logarithm of average wage (our proxy for productivity) for firms in business groups and for synthetic controls. Treated firms correspond to group firms that receive a top-occupation worker from the same business group (Panels A and B), or group firms that send a top-occupation worker to other firms (Panel C). In Panels A and C average wage is computed using all the workers of the firm, while in Panel B it is computed using workers that worked at the firm before the treatment (stayers). The choice of synthetic controls is discussed in Section 5.2. 
Table 1: Summary Statistics of Number of Firms, Workers, and Firm Pairs

\begin{tabular}{lcc} 
Number of Firms & Total & Mean per Year \\
\hline All & 224,763 & 88,670 \\
Business Group & 314 & 252 \\
Non-Business Group & 224,449 & 88,418 \\
\hline Number of Workers & Total & Mean per Year \\
\hline All & $7,024,887$ & $3,487,028$ \\
Business Group & 332,977 & 103,547 \\
Non-Business Group & $6,956,090$ & $3,383,481$ \\
\hline Number of Workers per Firm & Total & Mean per Year \\
\hline All & 31 & 39 \\
Business Group & 1,060 & 411 \\
Non-Business Group & 31 & 38 \\
\hline Number of Firm Pairs & Total & Mean per Year \\
\hline Business Group - All & 85,970 & 9,809 \\
Business Group - Business Group & 3,340 & 556 \\
Business Group - Non Business Group & 82,630 & 9,253 \\
\hline
\end{tabular}

Notes: This table documents, for the full sample of the employer-employee dataset, the number of firms, business group firms, non-business group firms; the number of workers in all firms, in business group and non-business group firms; the number of firm pairs involved in worker flows starting from business group firms and going to both business group and non-business group firms; and the average number of workers per firm, for all firms, business group firms and non-business group firms. It reports these statistics for both unique values of the whole dataset and also the mean number per year. Note that the number of workers per firm can be obtained by dividing the total number of workers and the number of firms reported in this table. A similar table for the sample of importers and exporters can be found in Table A.2 in the appendix. 
Table 2: Summary Statistics of Worker Flows, Wage Changes of Movers, and Wage Levels

\begin{tabular}{lrrrrr} 
& & \multicolumn{3}{c}{ Means (across firm-pair-years) } \\
\cline { 3 - 6 } & \multirow{2}{*}{ Pairs of Firms } & \multicolumn{3}{c}{ by quartiles of wage distribution } \\
\cline { 3 - 6 } & Business Group - Unaffiliated & 1.4 & 1.2 & 1.4 & 1.4 \\
\hline \multirow{2}{*}{ Number of Employees Sent } & Bottom 25 & Mid 50 & Top 25 \\
& Business Group - Business Group & 3.9 & 2.2 & 3.3 & 2.6 \\
\hline Share of Employees Sent (\%) & Business Group - Unaffiliated & 2.1 & 3.8 & 4.5 & 11.2 \\
& Business Group - Business Group & 11.5 & 15.3 & 19.3 & 29.5 \\
\hline \multirow{2}{*}{ Wage Changes of Movers (\%) } & Business Group - Unaffiliated & 3.6 & 7.7 & 1.6 & -6.2 \\
& Business Group - Business Group & 12.1 & 18.9 & 10.4 & 8.5 \\
\hline
\end{tabular}

\begin{tabular}{lrrrr} 
& \multicolumn{4}{c}{ Mean (across firm-years) } \\
\cline { 2 - 5 } & & \multicolumn{3}{c}{$\begin{array}{c}\text { By quartiles of the within-firm } \\
\text { wage distribution }\end{array}$} \\
\cline { 3 - 5 } Wages (relative to bottom-25th percentile) & All & Bottom 25 & Mid 50 & Top 25 \\
\hline Non-Business Group Firms (Bottom 25=USD 594) & 1.4 & 1 & 1.2 & 2.1 \\
Business Group Firms (Bottom 25=USD 1161) & 1.6 & 1 & 1.4 & 2.5 \\
\hline
\end{tabular}

Notes: This table reports statistics of worker flows, wage changes, and wage levels for the complete employer-employee sample. The upper panel shows statistics of worker flows between firm pairs, averaged across years. It shows both the number of workers sent from business group firms to other types of firms, the share of workers sent relative to the total number of workers sent by the origin firm, and wage changes of those workers that move between different types of firms. The lower panel shows the average wages for different types of firms, relative to the level of wages in the lower $25 \%$ of the wage distribution within each firm. 
Table 3: Internal Labor Mobility: Worker Flows Between Affiliated and Unaffiliated Firm Pairs

\begin{tabular}{|c|c|c|c|c|}
\hline & $\begin{array}{c}\text { All } \\
\text { Workers }\end{array}$ & $\begin{array}{l}\text { Bot. } 25 \\
\text { Workers }\end{array}$ & $\begin{array}{l}\text { Mid. } 50 \\
\text { Workers }\end{array}$ & $\begin{array}{c}\text { Top } 25 \\
\text { Workers }\end{array}$ \\
\hline & $(1)$ & $(2)$ & $(3)$ & $(4)$ \\
\hline Same Business Group & $\begin{array}{c}0.040^{* * *} \\
(0.006)\end{array}$ & $\begin{array}{c}0.032^{* * *} \\
(0.007)\end{array}$ & $\begin{array}{c}0.050^{* * *} \\
(0.008)\end{array}$ & $\begin{array}{c}0.058^{* * *} \\
(0.013)\end{array}$ \\
\hline Log Avg. Wage Origin & $\begin{array}{c}0.032^{* * *} \\
(0.011)\end{array}$ & $\begin{array}{c}0.020 \\
(0.013)\end{array}$ & $\begin{array}{l}0.025^{*} \\
(0.015)\end{array}$ & $\begin{array}{l}0.065^{*} \\
(0.033)\end{array}$ \\
\hline Log Avg. Wage Destination & $\begin{array}{l}-0.000 \\
(0.002)\end{array}$ & $\begin{array}{c}-0.006^{*} \\
(0.003)\end{array}$ & $\begin{array}{l}-0.003 \\
(0.004)\end{array}$ & $\begin{array}{c}-0.024^{*} \\
(0.013)\end{array}$ \\
\hline Log Employment Destination & $\begin{array}{c}-0.002^{* * *} \\
(0.001)\end{array}$ & $\begin{array}{c}-0.003^{* *} \\
(0.001)\end{array}$ & $\begin{array}{c}-0.005^{* * *} \\
(0.001)\end{array}$ & $\begin{array}{c}-0.013^{* * *} \\
(0.004)\end{array}$ \\
\hline Log Employment Origin & $\begin{array}{c}-0.048^{* * *} \\
(0.005)\end{array}$ & $\begin{array}{c}-0.090^{* * *} \\
(0.009)\end{array}$ & $\begin{array}{c}-0.081^{* * *} \\
(0.008)\end{array}$ & $\begin{array}{c}-0.145^{* * *} \\
(0.013)\end{array}$ \\
\hline Log Emp. Business Group Origin & $\begin{array}{c}0.050 \\
(0.052)\end{array}$ & $\begin{array}{c}0.044 \\
(0.140)\end{array}$ & $\begin{array}{c}0.126^{*} \\
(0.073)\end{array}$ & $\begin{array}{c}0.425^{\text {*** }} \\
(0.149)\end{array}$ \\
\hline Log Emp. Business Group Dest. & $\begin{array}{c}-0.146^{* * *} \\
(0.048)\end{array}$ & $\begin{array}{c}-0.194^{* *} \\
(0.075)\end{array}$ & $\begin{array}{c}-0.219^{* *} \\
(0.099)\end{array}$ & $\begin{array}{c}-0.260 \\
(0.179)\end{array}$ \\
\hline Log N. Firms Business Group Origin & $\begin{array}{c}0.015 \\
(0.021)\end{array}$ & $\begin{array}{c}0.018 \\
(0.042)\end{array}$ & $\begin{array}{c}0.018 \\
(0.032)\end{array}$ & $\begin{array}{c}-0.014 \\
(0.055)\end{array}$ \\
\hline Log N. Firms Business Group Dest. & $\begin{array}{c}0.001 \\
(0.018) \\
\end{array}$ & $\begin{array}{c}0.006 \\
(0.025) \\
\end{array}$ & $\begin{array}{c}0.003 \\
(0.026) \\
\end{array}$ & $\begin{array}{l}-0.144 \\
(0.092)\end{array}$ \\
\hline$R^{2}$ & 0.658 & 0.727 & 0.697 & 0.733 \\
\hline Origin FE & $\checkmark$ & $\checkmark$ & $\checkmark$ & $\checkmark$ \\
\hline Destination FE & $\checkmark$ & $\checkmark$ & $\checkmark$ & $\checkmark$ \\
\hline Year FE & $\checkmark$ & $\checkmark$ & $\checkmark$ & $\checkmark$ \\
\hline Mean DV & .023 & .040 & .051 & .127 \\
\hline SD DV & .067 & .096 & .117 & .200 \\
\hline Mean Numerator DV & 1.3 & 1.1 & 1.3 & 1.3 \\
\hline Number of Observations & 93022 & 45091 & 37046 & 11887 \\
\hline
\end{tabular}

Notes: This table reports the results from the regression presented in Equation (3.1). The dependent variable is the worker flows for all workers (column 1), for the bottom quartile workers in the within-firm wage distribution of the origin firm (column 2), for the middle quartiles (column 3), and for the top quartile (column 4). Same Business Group is a dummy that takes the value of one for those pairs of firms where the origin and the destination are part of the same business group. $\Delta$ Log Avg. Wage is the difference in the log average wage between destination and origin firms. Log Employment Origin (Destination) is the $\log$ total number of workers in the firm of origin (destination). Log Emp. Business Group Origin (Destination) is the log total number of workers in the business group of the firm of origin (destination). Log N. Firms Business Group Origin (Destination) is the log total number of firms that are part of the business group of the firm of origin (destination). Mean Numerator DV is the average of the numerator of the dependent variable. Robust standard errors in parentheses are double clustered at the level of the firm of origin and destination of the flow. $* * * \mathrm{p}<0.01,{ }^{* *} \mathrm{p}<0.05,{ }^{*} \mathrm{p}<0.1$. 
Table 4: Internal Labor Mobility: Controlling for Spatial and Industrial Proximity

\begin{tabular}{|c|c|c|c|c|}
\hline & $\begin{array}{c}\text { All } \\
\text { Workers }\end{array}$ & $\begin{array}{l}\text { Bot. } 25 \\
\text { Workers }\end{array}$ & $\begin{array}{l}\text { Mid. } 50 \\
\text { Workers }\end{array}$ & $\begin{array}{c}\text { Top } 25 \\
\text { Workers } \\
\end{array}$ \\
\hline & $(1)$ & $(2)$ & $(3)$ & $(4)$ \\
\hline Same Business Group & $\begin{array}{c}0.037^{* * *} \\
(0.007)\end{array}$ & $\begin{array}{c}0.032^{* * *} \\
(0.011)\end{array}$ & $\begin{array}{c}0.046^{* * *} \\
(0.012)\end{array}$ & $\begin{array}{c}0.085^{* * *} \\
(0.026)\end{array}$ \\
\hline Log Avg. Wage Origin & $\begin{array}{c}0.037^{* * *} \\
(0.014)\end{array}$ & $\begin{array}{l}-0.005 \\
(0.016)\end{array}$ & $\begin{array}{c}0.026^{* * *} \\
(0.010)\end{array}$ & $\begin{array}{c}0.090 \\
(0.057)\end{array}$ \\
\hline Log Avg. Wage Destination & $\begin{array}{l}-0.000 \\
(0.002)\end{array}$ & $\begin{array}{c}-0.004 \\
(0.004)\end{array}$ & $\begin{array}{c}0.002 \\
(0.004)\end{array}$ & $\begin{array}{l}-0.015 \\
(0.014)\end{array}$ \\
\hline Log Employment Destination & $\begin{array}{c}-0.001^{*} \\
(0.001)\end{array}$ & $\begin{array}{c}-0.002^{*} \\
(0.001)\end{array}$ & $\begin{array}{l}-0.002 \\
(0.002)\end{array}$ & $\begin{array}{c}-0.008^{* *} \\
(0.004)\end{array}$ \\
\hline Log Employment Origin & $\begin{array}{c}-0.052^{* * *} \\
(0.006)\end{array}$ & $\begin{array}{c}-0.096^{* * *} \\
(0.013)\end{array}$ & $\begin{array}{c}-0.085^{* * *} \\
(0.010)\end{array}$ & $\begin{array}{r}-0.130^{* * *} \\
(0.018)\end{array}$ \\
\hline Log Emp. Business Group Origin & $\begin{array}{c}0.070 \\
(0.069)\end{array}$ & $\begin{array}{c}0.072 \\
(0.179)\end{array}$ & $\begin{array}{c}0.185 \\
(0.117)\end{array}$ & $\begin{array}{c}0.645^{* * *} \\
(0.203)\end{array}$ \\
\hline Log Emp. Business Group Dest. & $\begin{array}{l}-0.030 \\
(0.042)\end{array}$ & $\begin{array}{c}0.020 \\
(0.077)\end{array}$ & $\begin{array}{c}0.072 \\
(0.086)\end{array}$ & $\begin{array}{l}-0.014 \\
(0.215)\end{array}$ \\
\hline Log N. Firms Business Group Origin & $\begin{array}{c}0.010 \\
(0.028)\end{array}$ & $\begin{array}{c}0.022 \\
(0.053)\end{array}$ & $\begin{array}{l}-0.011 \\
(0.045)\end{array}$ & $\begin{array}{l}-0.069 \\
(0.065)\end{array}$ \\
\hline Log N. Firms Business Group Dest. & $\begin{array}{c}0.003 \\
(0.013)\end{array}$ & $\begin{array}{l}-0.006 \\
(0.015)\end{array}$ & $\begin{array}{l}-0.004 \\
(0.025)\end{array}$ & $\begin{array}{c}-0.137^{* *} \\
(0.062)\end{array}$ \\
\hline$R^{2}$ & 0.730 & 0.802 & 0.789 & 0.827 \\
\hline Origin FE & $\checkmark$ & $\checkmark$ & $\checkmark$ & $\checkmark$ \\
\hline Destination FE & $\checkmark$ & $\checkmark$ & $\checkmark$ & $\checkmark$ \\
\hline Year FE & $\checkmark$ & $\checkmark$ & $\checkmark$ & $\checkmark$ \\
\hline Sector-Yr FE & $\checkmark$ & $\checkmark$ & $\checkmark$ & $\checkmark$ \\
\hline Location-Yr FE & $\checkmark$ & $\checkmark$ & $\checkmark$ & $\checkmark$ \\
\hline Mean DV & .021 & .035 & .044 & .105 \\
\hline SD DV & .062 & .087 & .103 & .178 \\
\hline Mean Numerator DV & 1.3 & 1.1 & 1.3 & 1.3 \\
\hline Number of Observations & 81818 & 36610 & 29511 & 7612 \\
\hline
\end{tabular}

Notes: This table reports the results from the regression presented in Equation (3.1) with industry-pairtimes-year and location-pair-times-year fixed effects. The dependent variable is the worker flows for all workers (column 1), for the bottom quartile workers in the within-firm wage distribution of the origin firm (column 2), for the middle quartiles (column 3), and for the top quartile (column 4). Same Business Group is a dummy that takes the value of one for those pairs of firms where the origin and the destination are part of the same business group. See Table 3 for variable definitions. Mean Numerator DV is the average of the numerator of the dependent variable. Robust standard errors in parentheses are double clustered at the level of the firm of origin and destination of the flow. ${ }^{* * *} \mathrm{p}<0.01,{ }^{* *} \mathrm{p}<0.05,{ }^{*} \mathrm{p}<0.1$. 
Table 5: Internal Labor Reallocation using Shocks to Industry-Level Tobin's Q

\begin{tabular}{|c|c|c|c|c|}
\hline & $\begin{array}{c}\text { All } \\
\text { Workers }\end{array}$ & $\begin{array}{l}\text { Bot. 25 } \\
\text { Workers }\end{array}$ & $\begin{array}{l}\text { Mid. } 50 \\
\text { Workers }\end{array}$ & $\begin{array}{c}\text { Top } 25 \\
\text { Workers }\end{array}$ \\
\hline & $(1)$ & $(2)$ & $(3)$ & $(4)$ \\
\hline$\Delta \mathrm{Q} \times$ Same Business Group & $\begin{array}{c}0.008 \\
(0.006)\end{array}$ & $\begin{array}{l}0.011^{*} \\
(0.006)\end{array}$ & $\begin{array}{c}0.007 \\
(0.006)\end{array}$ & $\begin{array}{l}0.024^{* *} \\
(0.011)\end{array}$ \\
\hline$\Delta \mathrm{Q}$ & $\begin{array}{c}0.000 \\
(0.000)\end{array}$ & $\begin{array}{c}0.001 \\
(0.001)\end{array}$ & $\begin{array}{c}0.000 \\
(0.001)\end{array}$ & $\begin{array}{c}0.002 \\
(0.002)\end{array}$ \\
\hline Same Business Group & $\begin{array}{c}0.039^{* * *} \\
(0.005)\end{array}$ & $\begin{array}{c}0.032^{* * *} \\
(0.007)\end{array}$ & $\begin{array}{c}0.051^{* * *} \\
(0.008)\end{array}$ & $\begin{array}{c}0.058^{* * *} \\
(0.015)\end{array}$ \\
\hline Log Avg. Wage Origin & $\begin{array}{c}0.053^{* * *} \\
(0.014)\end{array}$ & $\begin{array}{l}0.028^{*} \\
(0.015)\end{array}$ & $\begin{array}{l}0.042^{*} \\
(0.021)\end{array}$ & $\begin{array}{l}0.094^{* *} \\
(0.037)\end{array}$ \\
\hline Log Avg. Wage Destination & $\begin{array}{l}-0.001 \\
(0.003)\end{array}$ & $\begin{array}{l}-0.006 \\
(0.005)\end{array}$ & $\begin{array}{l}-0.005 \\
(0.005)\end{array}$ & $\begin{array}{l}-0.032^{*} \\
(0.018)\end{array}$ \\
\hline Log Employment Destination & $\begin{array}{c}-0.002^{* * *} \\
(0.001)\end{array}$ & $\begin{array}{c}-0.005^{* *} \\
(0.002)\end{array}$ & $\begin{array}{c}-0.007^{* * *} \\
(0.002)\end{array}$ & $\begin{array}{c}-0.015^{* * *} \\
(0.005)\end{array}$ \\
\hline Log Employment Origin & $\begin{array}{c}-0.052^{* * *} \\
(0.006)\end{array}$ & $\begin{array}{c}-0.098^{* * *} \\
(0.011)\end{array}$ & $\begin{array}{c}-0.088^{* * *} \\
(0.010)\end{array}$ & $\begin{array}{c}-0.143^{* * *} \\
(0.014)\end{array}$ \\
\hline Log Emp. Business Group Origin & $\begin{array}{c}0.030 \\
(0.042)\end{array}$ & $\begin{array}{l}-0.049 \\
(0.146)\end{array}$ & $\begin{array}{l}0.133^{* *} \\
(0.056)\end{array}$ & $\begin{array}{l}0.369^{* *} \\
(0.175)\end{array}$ \\
\hline Log Emp. Business Group Dest. & $\begin{array}{c}-0.170^{* * *} \\
(0.055)\end{array}$ & $\begin{array}{l}-0.128 \\
(0.095)\end{array}$ & $\begin{array}{c}-0.212^{* *} \\
(0.098)\end{array}$ & $\begin{array}{l}-0.332 \\
(0.221)\end{array}$ \\
\hline Log N. Firms Business Group Origin & $\begin{array}{c}0.028 \\
(0.027)\end{array}$ & $\begin{array}{c}0.051 \\
(0.063)\end{array}$ & $\begin{array}{c}0.031 \\
(0.038)\end{array}$ & $\begin{array}{c}0.003 \\
(0.097)\end{array}$ \\
\hline Log N. Firms Business Group Dest. & $\begin{array}{c}0.027 \\
(0.027)\end{array}$ & $\begin{array}{l}0.058^{*} \\
(0.030)\end{array}$ & $\begin{array}{c}0.004 \\
(0.041)\end{array}$ & $\begin{array}{l}-0.133 \\
(0.199)\end{array}$ \\
\hline$R^{2}$ & 0.666 & 0.746 & 0.712 & 0.755 \\
\hline Origin FE & $\checkmark$ & $\checkmark$ & $\checkmark$ & $\checkmark$ \\
\hline $\begin{array}{l}\text { Destination FE } \\
\text { Pair FE }\end{array}$ & $\checkmark$ & $\checkmark$ & $\checkmark$ & $\checkmark$ \\
\hline Year FE & $\checkmark$ & $\checkmark$ & $\checkmark$ & $\checkmark$ \\
\hline Mean DV & .028 & .047 & .058 & .136 \\
\hline SD DV & 0.75 & .107 & .127 & .205 \\
\hline Mean Numerator DV & 1.4 & 1.4 & 1.5 & 1.5 \\
\hline Number of Observations & 50593 & 22817 & 21161 & 7436 \\
\hline
\end{tabular}

Notes: This table reports the results from the regression presented in Equation (3.2). $\Delta$ Q is defined as the percentage difference in Tobin's Q between two consecutive years and between the destination and origin industries. Tobin's $\mathrm{Q}$ is defined as the ratio between the market and book value of assets at the industry level of listed firms. See Table 3 for variable definitions. Mean Numerator DV is the average of the numerator of the dependent variable. Robust standard errors in parentheses are double clustered at the level of the firm of origin and destination of the flow. ${ }^{* * *} \mathrm{p}<0.01,{ }^{* *} \mathrm{p}<0.05,{ }^{*} \mathrm{p}<0.1$. 
Table 6: Internal Labor Reallocation using Tobin's Q and Pair Fixed Effects

\begin{tabular}{|c|c|c|c|c|}
\hline & $\begin{array}{c}\text { All } \\
\text { Workers }\end{array}$ & $\begin{array}{l}\text { Bot. } 25 \\
\text { Workers }\end{array}$ & $\begin{array}{l}\text { Mid. } 50 \\
\text { Workers }\end{array}$ & $\begin{array}{c}\text { Top } 25 \\
\text { Workers } \\
\end{array}$ \\
\hline & $(1)$ & $(2)$ & $(3)$ & $(4)$ \\
\hline$\Delta \mathrm{Q} \times$ Same Business Group & $\begin{array}{c}0.009 \\
(0.007)\end{array}$ & $\begin{array}{c}0.012 \\
(0.008)\end{array}$ & $\begin{array}{c}0.004 \\
(0.007)\end{array}$ & $\begin{array}{l}0.022^{* *} \\
(0.009)\end{array}$ \\
\hline$\Delta \mathrm{Q}$ & $\begin{array}{l}-0.000 \\
(0.000)\end{array}$ & $\begin{array}{c}0.001 \\
(0.001)\end{array}$ & $\begin{array}{c}0.000 \\
(0.000)\end{array}$ & $\begin{array}{c}0.002 \\
(0.002)\end{array}$ \\
\hline Log Avg. Wage Origin & $\begin{array}{l}0.037^{* *} \\
(0.014)\end{array}$ & $\begin{array}{c}0.001 \\
(0.010)\end{array}$ & $\begin{array}{c}0.025 \\
(0.022)\end{array}$ & $\begin{array}{c}0.116 \\
(0.067)\end{array}$ \\
\hline Log Avg. Wage Destination & $\begin{array}{l}-0.003 \\
(0.005)\end{array}$ & $\begin{array}{c}-0.014 \\
(0.009)\end{array}$ & $\begin{array}{l}-0.011 \\
(0.011)\end{array}$ & $\begin{array}{c}-0.064^{* *} \\
(0.026)\end{array}$ \\
\hline Log Employment Destination & $\begin{array}{c}-0.004^{* *} \\
(0.001)\end{array}$ & $\begin{array}{l}-0.005^{*} \\
(0.003)\end{array}$ & $\begin{array}{c}-0.008^{* *} \\
(0.003)\end{array}$ & $\begin{array}{c}-0.023^{* *} \\
(0.008)\end{array}$ \\
\hline Log Employment Origin & $\begin{array}{c}-0.035^{* * *} \\
(0.004)\end{array}$ & $\begin{array}{c}-0.073^{* * *} \\
(0.015)\end{array}$ & $\begin{array}{c}-0.061^{* * *} \\
(0.009)\end{array}$ & $\begin{array}{r}-0.115^{* * *} \\
(0.016)\end{array}$ \\
\hline Log Emp. Business Group Origin & $\begin{array}{c}0.041 \\
(0.022)\end{array}$ & $\begin{array}{c}0.046 \\
(0.141)\end{array}$ & $\begin{array}{c}0.115 \\
(0.068)\end{array}$ & $\begin{array}{c}0.657^{* * *} \\
(0.172)\end{array}$ \\
\hline Log Emp. Business Group Dest. & $\begin{array}{c}-0.168^{* *} \\
(0.058)\end{array}$ & $\begin{array}{l}-0.198 \\
(0.150)\end{array}$ & $\begin{array}{l}-0.254 \\
(0.154)\end{array}$ & $\begin{array}{c}-0.304 \\
(0.317)\end{array}$ \\
\hline Log N. Firms Business Group Origin & $\begin{array}{c}0.017 \\
(0.011)\end{array}$ & $\begin{array}{c}0.031 \\
(0.028)\end{array}$ & $\begin{array}{c}0.033 \\
(0.035)\end{array}$ & $\begin{array}{l}-0.053 \\
(0.076)\end{array}$ \\
\hline Log N. Firms Business Group Dest. & $\begin{array}{c}0.063 \\
(0.038)\end{array}$ & $\begin{array}{c}0.094 \\
(0.066)\end{array}$ & $\begin{array}{l}-0.000 \\
(0.067)\end{array}$ & $\begin{array}{c}0.085 \\
(0.229)\end{array}$ \\
\hline $\begin{array}{l}R^{2} \\
\text { Origin FE } \\
\text { Destination FE }\end{array}$ & 0.743 & 0.804 & 0.765 & 0.814 \\
\hline Pair FE & $\checkmark$ & $\checkmark$ & $\checkmark$ & $\checkmark$ \\
\hline Year FE & $\checkmark$ & $\checkmark$ & $\checkmark$ & $\checkmark$ \\
\hline Mean DV & .025 & .037 & .049 & .124 \\
\hline SD DV & .070 & .091 & .119 & .200 \\
\hline Mean Numerator DV & 1.4 & 1.4 & 1.5 & 1.5 \\
\hline Number of Observations & 24042 & 9712 & 9622 & 3023 \\
\hline
\end{tabular}

Notes: This table reports the results from the regression presented in Equation (3.2). $\Delta \mathrm{Q}$ is defined as the percentage difference in Tobin's Q between two consecutive years and between the destination and origin industries. Tobin's Q is defined as the ratio between the market and book value of assets at the industry level of listed firms. See Table 3 for variable definitions. Mean Numerator DV is the average of the numerator of the dependent variable. Robust standard errors in parentheses are double clustered at the level of the firm of origin and destination of the flow. ${ }^{* * *} \mathrm{p}<0.01,{ }^{* *} \mathrm{p}<0.05,{ }^{*} \mathrm{p}<0.1$. 
Table 7: Internal Labor Reallocation and International Trade Shocks

\begin{tabular}{|c|c|c|c|c|c|c|}
\hline & $\begin{array}{c}\text { All } \\
\text { Workers }\end{array}$ & $\begin{array}{l}\text { Bot. } 25 \\
\text { Workers }\end{array}$ & $\begin{array}{l}\text { Mid. } 50 \\
\text { Workers }\end{array}$ & $\begin{array}{c}\text { Top } 25 \\
\text { Workers }\end{array}$ & $\begin{array}{c}\text { Top } 20 \\
\text { Workers }\end{array}$ & $\begin{array}{c}\text { Top } 10 \\
\text { Workers } \\
\end{array}$ \\
\hline & $(1)$ & $(2)$ & $(3)$ & $(4)$ & $(5)$ & $(6)$ \\
\hline$\Delta$ Export Price x Same Business Group & $\begin{array}{l}0.004^{*} \\
(0.002)\end{array}$ & $\begin{array}{l}-0.000 \\
(0.002)\end{array}$ & $\begin{array}{c}0.008 \\
(0.005)\end{array}$ & $\begin{array}{l}0.032^{* *} \\
(0.013)\end{array}$ & $\begin{array}{l}0.027^{*} \\
(0.014)\end{array}$ & $\begin{array}{c}0.091^{* * *} \\
(0.029)\end{array}$ \\
\hline$\Delta$ Import Price $\mathrm{x}$ Same Business Group & $\begin{array}{l}-0.004 \\
(0.004)\end{array}$ & $\begin{array}{l}-0.009 \\
(0.007)\end{array}$ & $\begin{array}{c}-0.015^{*} \\
(0.009)\end{array}$ & $\begin{array}{l}-0.004 \\
(0.012)\end{array}$ & $\begin{array}{c}0.002 \\
(0.012)\end{array}$ & $\begin{array}{l}-0.002 \\
(0.020)\end{array}$ \\
\hline$\Delta$ Export Price & $\begin{array}{c}0.001 \\
(0.001)\end{array}$ & $\begin{array}{c}0.001 \\
(0.001)\end{array}$ & $\begin{array}{c}0.002 \\
(0.002)\end{array}$ & $\begin{array}{l}0.006 \\
(0.004)\end{array}$ & $\begin{array}{c}0.001 \\
(0.005)\end{array}$ & $\begin{array}{l}-0.018 \\
(0.012)\end{array}$ \\
\hline$\Delta$ Import Price & $\begin{array}{l}-0.001 \\
(0.001)\end{array}$ & $\begin{array}{c}0.001 \\
(0.001)\end{array}$ & $\begin{array}{l}-0.001 \\
(0.002)\end{array}$ & $\begin{array}{l}-0.002 \\
(0.002)\end{array}$ & $\begin{array}{l}-0.005 \\
(0.003)\end{array}$ & $\begin{array}{l}-0.003 \\
(0.008)\end{array}$ \\
\hline Same Business Group & $\begin{array}{c}0.022^{* * *} \\
(0.006)\end{array}$ & $\begin{array}{c}0.018^{* * *} \\
(0.007)\end{array}$ & $\begin{array}{l}0.024^{* *} \\
(0.010)\end{array}$ & $\begin{array}{c}0.044^{* * *} \\
(0.016)\end{array}$ & $\begin{array}{l}0.052^{* *} \\
(0.023)\end{array}$ & $\begin{array}{c}0.016 \\
(0.030)\end{array}$ \\
\hline Log Avg. Wage Origin & $\begin{array}{c}0.003 \\
(0.018)\end{array}$ & $\begin{array}{c}0.016 \\
(0.018)\end{array}$ & $\begin{array}{c}-0.012 \\
(0.017)\end{array}$ & $\begin{array}{c}0.046 \\
(0.080)\end{array}$ & $\begin{array}{c}0.051 \\
(0.079)\end{array}$ & $\begin{array}{l}0.254^{* *} \\
(0.120)\end{array}$ \\
\hline Log Avg. Wage Destination & $\begin{array}{c}0.000 \\
(0.003)\end{array}$ & $\begin{array}{l}-0.001 \\
(0.005)\end{array}$ & $\begin{array}{l}-0.002 \\
(0.008)\end{array}$ & $\begin{array}{l}-0.057 \\
(0.038)\end{array}$ & $\begin{array}{l}-0.066 \\
(0.046)\end{array}$ & $\begin{array}{l}-0.103 \\
(0.082)\end{array}$ \\
\hline Log Employment Destination & $\begin{array}{l}-0.002^{*} \\
(0.001)\end{array}$ & $\begin{array}{c}-0.004^{* *} \\
(0.002)\end{array}$ & $\begin{array}{l}-0.006^{*} \\
(0.003)\end{array}$ & $\begin{array}{c}-0.022^{* *} \\
(0.010)\end{array}$ & $\begin{array}{c}-0.027^{* *} \\
(0.012)\end{array}$ & $\begin{array}{c}-0.057^{* * *} \\
(0.018)\end{array}$ \\
\hline Log Employment Origin & $\begin{array}{c}-0.046^{* * *} \\
(0.009)\end{array}$ & $\begin{array}{c}-0.086^{* * *} \\
(0.017)\end{array}$ & $\begin{array}{c}-0.074^{* * *} \\
(0.012)\end{array}$ & $\begin{array}{c}-0.158^{* * *} \\
(0.030)\end{array}$ & $\begin{array}{c}-0.192^{* * *} \\
(0.030)\end{array}$ & $\begin{array}{c}-0.256^{* * *} \\
(0.040)\end{array}$ \\
\hline Log Emp. Business Group Origin & $\begin{array}{l}-0.083 \\
(0.079)\end{array}$ & $\begin{array}{l}-0.281 \\
(0.175)\end{array}$ & $\begin{array}{l}-0.149 \\
(0.248)\end{array}$ & $\begin{array}{c}0.301 \\
(0.326)\end{array}$ & $\begin{array}{c}0.267 \\
(0.426)\end{array}$ & $\begin{array}{c}0.429 \\
(0.609)\end{array}$ \\
\hline Log Emp. Business Group Destination & $\begin{array}{c}-0.119^{* *} \\
(0.049)\end{array}$ & $\begin{array}{c}-0.287^{* * *} \\
(0.099)\end{array}$ & $\begin{array}{l}-0.137 \\
(0.143)\end{array}$ & $\begin{array}{l}-0.209 \\
(0.215)\end{array}$ & $\begin{array}{c}0.011 \\
(0.297)\end{array}$ & $\begin{array}{c}0.721 \\
(0.728)\end{array}$ \\
\hline Log N. Firms Business Group Origin & $\begin{array}{l}0.068^{*} \\
(0.037)\end{array}$ & $\begin{array}{c}0.098^{*} \\
(0.056)\end{array}$ & $\begin{array}{l}0.081^{* *} \\
(0.039)\end{array}$ & $\begin{array}{l}0.390^{* *} \\
(0.168)\end{array}$ & $\begin{array}{l}0.404^{* *} \\
(0.184)\end{array}$ & $\begin{array}{c}0.376 \\
(0.280)\end{array}$ \\
\hline Log N. Firms Business Group Destination & $\begin{array}{c}0.013 \\
(0.016)\end{array}$ & $\begin{array}{c}0.018 \\
(0.021)\end{array}$ & $\begin{array}{c}0.030 \\
(0.032)\end{array}$ & $\begin{array}{l}-0.029 \\
(0.171)\end{array}$ & $\begin{array}{l}-0.033 \\
(0.224)\end{array}$ & $\begin{array}{c}0.590 \\
(0.881)\end{array}$ \\
\hline$R^{2}$ & 0.594 & 0.680 & 0.639 & 0.697 & 0.688 & 0.758 \\
\hline Origin FE & $\checkmark$ & $\checkmark$ & $\checkmark$ & $\checkmark$ & $\checkmark$ & $\checkmark$ \\
\hline Destination FE & $\checkmark$ & $\checkmark$ & $\checkmark$ & $\checkmark$ & $\checkmark$ & $\checkmark$ \\
\hline Year FE & $\checkmark$ & $\checkmark$ & $\checkmark$ & $\checkmark$ & $\checkmark$ & $\checkmark$ \\
\hline Mean DV & .02 & .037 & .047 & .122 & .144 & .23 \\
\hline SD DV & .042 & .066 & .084 & .16 & .181 & .249 \\
\hline Mean Numerator DV & 1.3 & 1.1 & 1.3 & 1.5 & 1.4 & 1.4 \\
\hline Number of observations & 20188 & 9184 & 7523 & 2457 & 1974 & 922 \\
\hline
\end{tabular}

Notes: This table reports the results from the regression presented in Equation (3.2). $\Delta$ Exports ( $\Delta$ Imports) is defined as the log difference in firm-level export (imports) prices between two consecutive years and between the destination and the origin firms (see Section 2.3). See Table 3 for variable definitions. Mean Numerator DV is the average of the numerator of the dependent variable. Robust standard errors in parentheses are double clustered at the level of the firm of origin and destination of the flow. ${ }^{* * *} \mathrm{p}<0.01$, ${ }^{* *} \mathrm{p}<0.05,{ }^{*} \mathrm{p}<0.1$. 
Table 8: Job-to-Job Wage Changes for Movers

\begin{tabular}{|c|c|c|c|c|c|}
\hline & $\begin{array}{c}\text { All } \\
\text { Workers }\end{array}$ & $\begin{array}{l}\text { Bot. } 25 \\
\text { Workers } \\
\end{array}$ & $\begin{array}{l}\text { Mid. } 50 \\
\text { Workers }\end{array}$ & $\begin{array}{c}\text { Top } 25 \\
\text { Workers } \\
\end{array}$ & $\begin{array}{c}\text { Top } 25 \text { versus } \\
\text { Stayers at Destination }\end{array}$ \\
\hline & $(1)$ & $(2)$ & $(3)$ & $(4)$ & $(5)$ \\
\hline$\Delta$ Export Price x Same Business Group & $\begin{array}{l}-0.001 \\
(0.007)\end{array}$ & $\begin{array}{c}-0.012 \\
(0.012)\end{array}$ & $\begin{array}{c}0.006 \\
(0.013)\end{array}$ & $\begin{array}{c}0.066^{* * *} \\
(0.021)\end{array}$ & $\begin{array}{l}0.048^{* *} \\
(0.023)\end{array}$ \\
\hline$\Delta$ Import Price x Same Business Group & $\begin{array}{c}0.009 \\
(8.057)\end{array}$ & $\begin{array}{c}0.026 \\
(4.033)\end{array}$ & $\begin{array}{c}0.005 \\
(0.008)\end{array}$ & $\begin{array}{c}0.009 \\
(0.014)\end{array}$ & $\begin{array}{c}0.004 \\
(0.016)\end{array}$ \\
\hline$\Delta$ Export Price & $\begin{array}{l}-0.000 \\
(0.003)\end{array}$ & $\begin{array}{c}0.005 \\
(0.005)\end{array}$ & $\begin{array}{l}-0.002 \\
(0.005)\end{array}$ & $\begin{array}{c}-0.009 \\
(0.008)\end{array}$ & $\begin{array}{l}-0.002 \\
(0.009)\end{array}$ \\
\hline$\Delta$ Imports Price & $\begin{array}{c}-0.009^{* *} \\
(0.004)\end{array}$ & $\begin{array}{l}-0.005 \\
(0.005)\end{array}$ & $\begin{array}{l}-0.009 \\
(0.006)\end{array}$ & $\begin{array}{l}-0.007 \\
(0.008)\end{array}$ & $\begin{array}{l}-0.007 \\
(0.008)\end{array}$ \\
\hline Same Business Group & $\begin{array}{l}-0.005 \\
(0.022)\end{array}$ & $\begin{array}{l}-0.026 \\
(0.038)\end{array}$ & $\begin{array}{c}0.012 \\
(0.041)\end{array}$ & $\begin{array}{l}0.085^{*} \\
(0.046)\end{array}$ & $\begin{array}{c}0.075 \\
(0.052)\end{array}$ \\
\hline Log Avg. Wage Origin & $\begin{array}{c}-0.431^{* * *} \\
(0.033)\end{array}$ & $\begin{array}{c}-0.609^{* * *} \\
(0.044)\end{array}$ & $\begin{array}{c}-0.538^{* * *} \\
(0.047)\end{array}$ & $\begin{array}{c}-0.450^{* * *} \\
(0.056)\end{array}$ & $\begin{array}{c}-0.441^{* * *} \\
(0.054)\end{array}$ \\
\hline Log Avg. Wage Destination & $\begin{array}{l}0.100^{* *} \\
(0.041)\end{array}$ & $\begin{array}{c}0.042 \\
(0.035)\end{array}$ & $\begin{array}{c}0.060 \\
(0.043)\end{array}$ & $\begin{array}{c}0.072 \\
(0.083)\end{array}$ & $\begin{array}{c}0.317^{* * *} \\
(0.090)\end{array}$ \\
\hline Log Employment Destination & $\begin{array}{c}-0.011 \\
(0.016)\end{array}$ & $\begin{array}{c}-0.049^{* *} \\
(0.022)\end{array}$ & $\begin{array}{l}-0.015 \\
(0.017)\end{array}$ & $\begin{array}{l}-0.008 \\
(0.027)\end{array}$ & $\begin{array}{l}-0.049 \\
(0.030)\end{array}$ \\
\hline Log Employment Origin & $\begin{array}{c}-0.057^{* * *} \\
(0.008)\end{array}$ & $\begin{array}{c}-0.034^{* *} \\
(0.014)\end{array}$ & $\begin{array}{c}-0.044^{* * *} \\
(0.011)\end{array}$ & $\begin{array}{c}-0.055^{* *} \\
(0.026)\end{array}$ & $\begin{array}{l}-0.050^{*} \\
(0.026)\end{array}$ \\
\hline Log Emp. Business Group Origin & $\begin{array}{l}0.230 \\
(0.334)\end{array}$ & $\begin{array}{c}0.047 \\
(0.384)\end{array}$ & $\begin{array}{c}0.451 \\
(0.441)\end{array}$ & $\begin{array}{l}-0.665 \\
(0.629)\end{array}$ & $\begin{array}{l}-0.476 \\
(0.753)\end{array}$ \\
\hline Log Emp. Business Group Destination & $\begin{array}{c}0.088 \\
(0.334)\end{array}$ & $\begin{array}{c}0.369 \\
(0.389)\end{array}$ & $\begin{array}{c}0.275 \\
(0.418)\end{array}$ & $\begin{array}{l}-0.619 \\
(0.500)\end{array}$ & $\begin{array}{c}0.676 \\
(0.464)\end{array}$ \\
\hline Log N. Firms Business Group Origin & $\begin{array}{l}-0.008 \\
(0.185)\end{array}$ & $\begin{array}{c}-0.050 \\
(0.148)\end{array}$ & $\begin{array}{l}-0.136 \\
(0.184)\end{array}$ & $\begin{array}{c}-0.071 \\
(0.358)\end{array}$ & $\begin{array}{c}0.236 \\
(0.353)\end{array}$ \\
\hline Log N. Firms Business Group Destination & $\begin{array}{c}0.187 \\
(0.192)\end{array}$ & $\begin{array}{c}0.162 \\
(0.206)\end{array}$ & $\begin{array}{c}0.266 \\
(0.216)\end{array}$ & $\begin{array}{c}0.383 \\
(0.428)\end{array}$ & $\begin{array}{c}0.195 \\
(0.428)\end{array}$ \\
\hline$R^{2}$ & 0.465 & 0.527 & 0.567 & 0.524 & 0.548 \\
\hline Origin FE & $\checkmark$ & $\checkmark$ & $\checkmark$ & $\checkmark$ & $\checkmark$ \\
\hline Destination FE & $\checkmark$ & $\checkmark$ & $\checkmark$ & $\checkmark$ & $\checkmark$ \\
\hline Year FE & $\checkmark$ & $\checkmark$ & $\checkmark$ & $\checkmark$ & $\checkmark$ \\
\hline Mean DV & .2 & .243 & .176 & .134 & .087 \\
\hline SD DV & .411 & .428 & .404 & .356 & .374 \\
\hline Number of observations & 20012 & 7384 & 9274 & 2608 & 2516 \\
\hline
\end{tabular}

Notes: This table reports the results from the regression presented in Equation (3.2). The dependent variable is the log difference of wages for the workers that move (movers) between the destination and the origin firm. Column 5 has the same dependent variable as column 4, with the exception that it subtracts the $\log$ difference of wages for stayers in the destination firm. This is done to address the concern of mechanical wage gains for movers due to wage gains that the destination firm is experiencing. $\Delta$ Exports ( $\Delta$ Imports) is defined as the log difference in firm-level export (imports) prices between two consecutive years and between the destination and the origin firms (see Section 2.3). See Table 3 for variable definitions. Robust standard errors in parentheses are double clustered at the level of the firm of origin and destination of the flow. ${ }^{* * *} \mathrm{p}<0.01,{ }^{*} \mathrm{p}<0.05,{ }^{*} \mathrm{p}<0.1$. 
Table 9: Internal Labor Reallocation: Evidence from Within-Group Worker Flows

\begin{tabular}{|c|c|c|c|c|c|c|}
\hline & $\begin{array}{c}\text { All } \\
\text { Workers }\end{array}$ & $\begin{array}{l}\text { Bot. } 25 \\
\text { Workers }\end{array}$ & $\begin{array}{l}\text { Mid. } 50 \\
\text { Workers }\end{array}$ & $\begin{array}{c}\text { Top } 25 \\
\text { Workers }\end{array}$ & $\begin{array}{c}\text { Top } 20 \\
\text { Workers }\end{array}$ & $\begin{array}{c}\text { Top } 10 \\
\text { Workers }\end{array}$ \\
\hline & $(1)$ & $(2)$ & $(3)$ & $(4)$ & $(5)$ & $(6)$ \\
\hline$\Delta$ Export Price & $\begin{array}{l}0.004^{*} \\
(0.002)\end{array}$ & $\begin{array}{c}0.001 \\
(0.001)\end{array}$ & $\begin{array}{l}0.013^{*} \\
(0.007)\end{array}$ & $\begin{array}{l}0.036^{* *} \\
(0.017)\end{array}$ & $\begin{array}{l}0.026^{*} \\
(0.015)\end{array}$ & $\begin{array}{l}0.045^{* *} \\
(0.022)\end{array}$ \\
\hline$\Delta$ Import Price & $\begin{array}{l}-0.005 \\
(0.003)\end{array}$ & $\begin{array}{l}-0.005 \\
(0.004)\end{array}$ & $\begin{array}{l}-0.006 \\
(0.010)\end{array}$ & $\begin{array}{l}-0.011 \\
(0.016)\end{array}$ & $\begin{array}{l}-0.008 \\
(0.017)\end{array}$ & $\begin{array}{l}-0.001 \\
(0.028)\end{array}$ \\
\hline Log Avg. Wage Origin & $\begin{array}{c}0.042 \\
(0.040)\end{array}$ & $\begin{array}{l}0.139^{* *} \\
(0.062)\end{array}$ & $\begin{array}{c}0.087 \\
(0.072)\end{array}$ & $\begin{array}{c}0.301 \\
(0.206)\end{array}$ & $\begin{array}{c}0.179 \\
(0.296)\end{array}$ & $\begin{array}{c}0.188 \\
(0.351)\end{array}$ \\
\hline Log Avg. Wage Destination & $\begin{array}{l}-0.139^{*} \\
(0.074)\end{array}$ & $\begin{array}{l}-0.064 \\
(0.039)\end{array}$ & $\begin{array}{c}-0.427^{* * *} \\
(0.147)\end{array}$ & $\begin{array}{c}-0.464^{* *} \\
(0.186)\end{array}$ & $\begin{array}{l}-0.342^{*} \\
(0.201)\end{array}$ & $\begin{array}{l}-0.257 \\
(0.335)\end{array}$ \\
\hline Log Employment Origin & $\begin{array}{c}-0.053^{* * *} \\
(0.016)\end{array}$ & $\begin{array}{c}-0.165^{* * *} \\
(0.039)\end{array}$ & $\begin{array}{l}-0.055^{*} \\
(0.029)\end{array}$ & $\begin{array}{c}-0.124^{* *} \\
(0.048)\end{array}$ & $\begin{array}{c}-0.198^{* * *} \\
(0.070)\end{array}$ & $\begin{array}{l}-0.095 \\
(0.060)\end{array}$ \\
\hline Log Employment Destination & $\begin{array}{l}-0.024 \\
(0.017)\end{array}$ & $\begin{array}{l}-0.031 \\
(0.021)\end{array}$ & $\begin{array}{c}-0.079^{* *} \\
(0.038)\end{array}$ & $\begin{array}{c}-0.077^{* * *} \\
(0.022)\end{array}$ & $\begin{array}{c}-0.074^{* * *} \\
(0.026)\end{array}$ & $\begin{array}{c}-0.255^{* * *} \\
(0.075)\end{array}$ \\
\hline Log Emp. Business Group & $\begin{array}{l}-0.383 \\
(0.371)\end{array}$ & $\begin{array}{l}-0.152 \\
(0.620)\end{array}$ & $\begin{array}{l}-0.217 \\
(0.851)\end{array}$ & $\begin{array}{c}1.854 \\
(1.384)\end{array}$ & $\begin{array}{l}3.954^{* *} \\
(1.577)\end{array}$ & $\begin{array}{l}-0.662 \\
(4.124)\end{array}$ \\
\hline Log N. Firms Business Group & $\begin{array}{c}0.063 \\
(0.205) \\
\end{array}$ & $\begin{array}{c}0.123 \\
(0.239) \\
\end{array}$ & $\begin{array}{l}-0.223 \\
(0.439) \\
\end{array}$ & $\begin{array}{c}0.152 \\
(0.503) \\
\end{array}$ & $\begin{array}{c}0.763 \\
(0.952) \\
\end{array}$ & $\begin{array}{c}0.656 \\
(1.127) \\
\end{array}$ \\
\hline$R^{2}$ & 0.591 & 0.797 & 0.651 & 0.753 & 0.742 & 0.837 \\
\hline Origin FE & $\checkmark$ & $\checkmark$ & $\checkmark$ & $\checkmark$ & $\checkmark$ & $\checkmark$ \\
\hline Destination FE & $\checkmark$ & $\checkmark$ & $\checkmark$ & $\checkmark$ & $\checkmark$ & $\checkmark$ \\
\hline Year FE & $\checkmark$ & $\checkmark$ & $\checkmark$ & $\checkmark$ & $\checkmark$ & $\checkmark$ \\
\hline Mean DV & .051 & .08 & .096 & .189 & .219 & .312 \\
\hline SD DV & .084 & .115 & .134 & .213 & .246 & .298 \\
\hline Mean Numerator DV & 4.9 & 2.1 & 4.4 & 3.1 & 2.8 & 2.4 \\
\hline Number of observations & 576 & 255 & 234 & 218 & 201 & 123 \\
\hline
\end{tabular}

Notes: This table reports the results from the regression presented in Equation (3.3) restricting the sample to only those flows that are within the same business group. $\Delta$ Exports $(\Delta \operatorname{Imports})$ is defined as the log difference in firm-level export (imports) prices between two consecutive years and between the destination and the origin firm (see Section 2.3). See Table 3 for variable definitions. Robust standard errors in parentheses are double clustered at the level of the firm of origin and destination of the flow. *** $\mathrm{p}<0.01, * * \mathrm{p}<0.05, * \mathrm{p}<0.1$. 


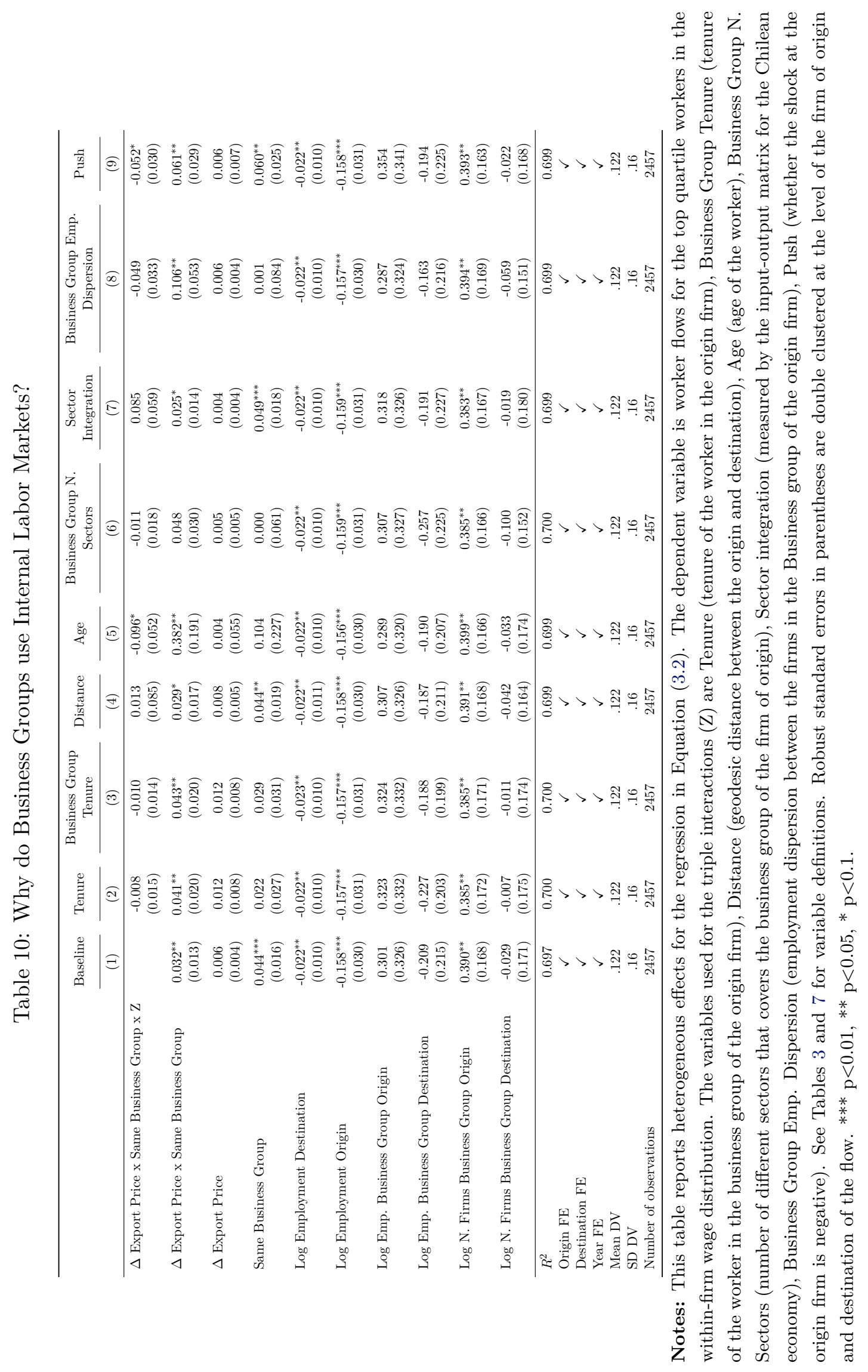


Table 11: Job-to-Job Wage Rank Changes for Movers

\begin{tabular}{|c|c|c|c|c|}
\hline & $\begin{array}{c}\text { All } \\
\text { Workers }\end{array}$ & $\begin{array}{l}\text { Bot. } 25 \\
\text { Workers }\end{array}$ & $\begin{array}{l}\text { Mid. } 50 \\
\text { Workers }\end{array}$ & $\begin{array}{c}\text { Top } 25 \\
\text { Workers }\end{array}$ \\
\hline & $(1)$ & $(2)$ & $(3)$ & $(4)$ \\
\hline$\Delta$ Export Price $\mathrm{x}$ Same Business Group & $\begin{array}{c}0.056^{* *} \\
(0.028)\end{array}$ & $\begin{array}{c}0.033 \\
(0.032)\end{array}$ & $\begin{array}{c}0.021 \\
(0.029)\end{array}$ & $\begin{array}{c}0.096^{* *} \\
(0.045)\end{array}$ \\
\hline$\Delta$ Import Price $\mathrm{x}$ Same Business Group & $\begin{array}{c}-0.001 \\
(0.013)\end{array}$ & $\begin{array}{c}0.112 \\
(2.851)\end{array}$ & $\begin{array}{c}0.020 \\
(0.019)\end{array}$ & $\begin{array}{c}-0.077^{\text {*** }} \\
(0.015)\end{array}$ \\
\hline$\Delta$ Export Price & $\begin{array}{c}-0.011 \\
(0.012)\end{array}$ & $\begin{array}{c}-0.024 \\
(0.017)\end{array}$ & $\begin{array}{c}0.011 \\
(0.010)\end{array}$ & $\begin{array}{c}-0.025 \\
(0.016)\end{array}$ \\
\hline$\Delta$ Import Price & $\begin{array}{c}0.009 \\
(0.013)\end{array}$ & $\begin{array}{c}0.024 \\
(0.018)\end{array}$ & $\begin{array}{c}0.018 \\
(0.014)\end{array}$ & $\begin{array}{c}-0.010 \\
(0.016)\end{array}$ \\
\hline Same Business Group & $\begin{array}{c}0.007 \\
(0.065)\end{array}$ & $\begin{array}{c}-0.052 \\
(0.104)\end{array}$ & $\begin{array}{c}0.014 \\
(0.072)\end{array}$ & $\begin{array}{c}0.039 \\
(0.065)\end{array}$ \\
\hline Log Avg. Wage Origin & $\begin{array}{c}0.197^{*} \\
(0.115)\end{array}$ & $\begin{array}{c}0.056 \\
(0.160)\end{array}$ & $\begin{array}{c}0.467^{* * *} \\
(0.108)\end{array}$ & $\begin{array}{c}-0.102 \\
(0.177)\end{array}$ \\
\hline Log Avg. Wage Destination & $\begin{array}{c}-0.348^{* * *} \\
(0.125)\end{array}$ & $\begin{array}{c}-0.226^{* *} \\
(0.109)\end{array}$ & $\begin{array}{c}-0.234^{* *} \\
(0.117)\end{array}$ & $\begin{array}{c}-0.043 \\
(0.118)\end{array}$ \\
\hline Log Employment Destination & $\begin{array}{c}-0.047^{* *} \\
(0.022)\end{array}$ & $\begin{array}{l}-0.040 \\
(0.041)\end{array}$ & $\begin{array}{c}-0.016 \\
(0.026)\end{array}$ & $\begin{array}{c}-0.001 \\
(0.033)\end{array}$ \\
\hline Log Employment Origin & $\begin{array}{c}-0.089 \\
(0.064)\end{array}$ & $\begin{array}{c}-0.045 \\
(0.090)\end{array}$ & $\begin{array}{c}-0.086^{*} \\
(0.050)\end{array}$ & $\begin{array}{r}-0.125^{*} \\
(0.065)\end{array}$ \\
\hline Log Emp. Business Group Origin & $\begin{array}{c}0.795 \\
(0.817)\end{array}$ & $\begin{array}{c}-0.717 \\
(0.944)\end{array}$ & $\begin{array}{l}1.787^{* *} \\
(0.677)\end{array}$ & $\begin{array}{c}-0.219 \\
(0.998)\end{array}$ \\
\hline Log Emp. Business Group Destination & $\begin{array}{c}0.717 \\
(0.805)\end{array}$ & $\begin{array}{c}-0.066 \\
(0.830)\end{array}$ & $\begin{array}{c}-0.327 \\
(0.989)\end{array}$ & $\begin{array}{c}3.501^{* * *} \\
(1.240)\end{array}$ \\
\hline Log N. Firms Business Group Origin & $\begin{array}{c}0.251 \\
(0.347)\end{array}$ & $\begin{array}{c}-0.710 \\
(0.467)\end{array}$ & $\begin{array}{c}0.266 \\
(0.239)\end{array}$ & $\begin{array}{c}0.418 \\
(0.308)\end{array}$ \\
\hline Log N. Firms Business Group Destination & $\begin{array}{c}0.612^{\text {*** }} \\
(0.204)\end{array}$ & $\begin{array}{c}0.858^{* *} \\
(0.361)\end{array}$ & $\begin{array}{c}0.433 \\
(0.401)\end{array}$ & $\begin{array}{l}1.692^{* *} \\
(0.735)\end{array}$ \\
\hline$R^{2}$ & 0.338 & 0.353 & 0.368 & 0.451 \\
\hline Origin FE & $\checkmark$ & $\checkmark$ & $\checkmark$ & $\checkmark$ \\
\hline Destination FE & $\checkmark$ & $\checkmark$ & $\checkmark$ & $\checkmark$ \\
\hline Year FE & $\checkmark$ & $\checkmark$ & $\checkmark$ & $\checkmark$ \\
\hline Mean DV & .271 & .99 & -.323 & -.452 \\
\hline SD DV & 1.245 & 1.274 & .918 & .681 \\
\hline Number of observations & 20188 & 9184 & 7523 & 2457 \\
\hline
\end{tabular}

Notes: This table reports the results from the regression presented in Equation (3.2). The dependent variable is the difference of wage rank within the firm for the workers that move (movers) between the destination and the origin firm. $\Delta$ Exports ( $\Delta$ Imports) is defined as the log difference in firm-level export (imports) prices between two consecutive years and between the destination and the origin as described in section 2.3. See Table 3 for variable definitions. Robust standard errors in parentheses are double clustered at the level of the firm of origin and destination of the flow. $* * * \mathrm{p}<0.01,{ }^{* *} \mathrm{p}<0.05,{ }^{*} \mathrm{p}<0.1$. 
Table 12: Internal Labor Reallocation and Ownership Structure

\begin{tabular}{|c|c|c|c|}
\hline & Baseline & $\begin{array}{c}\text { Origin Controls } \\
\text { Destination }\end{array}$ & $\begin{array}{c}\text { Business Group } \\
\text { Pyramidality }\end{array}$ \\
\hline & $(1)$ & $(2)$ & $(3)$ \\
\hline$\Delta$ Export Price x Same Business Group x Z & & $\begin{array}{c}0.424^{* * *} \\
(0.107)\end{array}$ & $\begin{array}{c}0.510^{* * *} \\
(0.156)\end{array}$ \\
\hline$\Delta$ Export Price x Same Business Group & $\begin{array}{l}0.032^{* *} \\
(0.013)\end{array}$ & $\begin{array}{l}0.038^{* *} \\
(0.015)\end{array}$ & $\begin{array}{c}0.019 \\
(0.012)\end{array}$ \\
\hline$\Delta$ Export Price & $\begin{array}{c}0.006 \\
(0.004)\end{array}$ & $\begin{array}{c}0.007 \\
(0.004)\end{array}$ & $\begin{array}{c}0.006 \\
(0.004)\end{array}$ \\
\hline Same Business Group & $\begin{array}{c}0.044^{* * *} \\
(0.016)\end{array}$ & $\begin{array}{c}0.022 \\
(0.021)\end{array}$ & $\begin{array}{l}0.035^{* *} \\
(0.017)\end{array}$ \\
\hline Log Employment Destination & $\begin{array}{c}-0.022^{* *} \\
(0.010)\end{array}$ & $\begin{array}{l}-0.017 \\
(0.010)\end{array}$ & $\begin{array}{c}-0.023^{* *} \\
(0.011)\end{array}$ \\
\hline Log Employment Origin & $\begin{array}{c}-0.158^{* * *} \\
(0.030)\end{array}$ & $\begin{array}{c}-0.162^{* * *} \\
(0.031)\end{array}$ & $\begin{array}{c}-0.158^{* * *} \\
(0.030)\end{array}$ \\
\hline Log Emp. Business Group Origin & $\begin{array}{c}0.301 \\
(0.326)\end{array}$ & $\begin{array}{c}0.324 \\
(0.332)\end{array}$ & $\begin{array}{c}0.308 \\
(0.327)\end{array}$ \\
\hline Log Emp. Business Group Destination & $\begin{array}{l}-0.209 \\
(0.215)\end{array}$ & $\begin{array}{l}-0.112 \\
(0.213)\end{array}$ & $\begin{array}{l}-0.152 \\
(0.188)\end{array}$ \\
\hline Log N. Firms Business Group Origin & $\begin{array}{l}0.390^{* *} \\
(0.168)\end{array}$ & $\begin{array}{l}0.390^{* *} \\
(0.169)\end{array}$ & $\begin{array}{l}0.384^{* *} \\
(0.172)\end{array}$ \\
\hline Log N. Firms Business Group Destination & $\begin{array}{l}-0.029 \\
(0.171) \\
\end{array}$ & $\begin{array}{l}-0.051 \\
(0.187) \\
\end{array}$ & $\begin{array}{l}-0.101 \\
(0.182) \\
\end{array}$ \\
\hline$R^{2}$ & 0.697 & 0.713 & 0.703 \\
\hline Origin FE & $\checkmark$ & $\checkmark$ & $\checkmark$ \\
\hline Destination FE & $\checkmark$ & $\checkmark$ & $\checkmark$ \\
\hline Year FE & $\checkmark$ & $\checkmark$ & $\checkmark$ \\
\hline Mean DV & .122 & .122 & .122 \\
\hline SD DV & .16 & .16 & .16 \\
\hline Mean Numerator DV & 1.1 & 1.1 & 1.1 \\
\hline Number of observations & 2457 & 2457 & 2457 \\
\hline
\end{tabular}

Notes: This table reports heterogeneous effects for the regression in Equation (3.2). The dependent variable is worker flows for the top quartile workers in the within-firm wage distribution. The variables used for the triple interactions (Z) are Origin Controls Dest. (a dummy that takes the value one if the origin firms has an ownership stake greater than $50 \%$ of the destination firm) and Business Group Pyramidality (a dummy for business groups with high pyramidality). $\Delta$ Exports ( $\Delta$ Imports) is defined as the log difference in firm-level export (imports) prices between two consecutive years and between the destination and the origin as described in section 2.3. See Table 3 for variable definitions. Mean Numerator DV is the average of the numerator of the dependent variable. Robust standard errors in parentheses are double clustered at the level of the firm of origin and destination of the flow. ${ }^{* * *} \mathrm{p}<0.01, * * \mathrm{p}<0.05,{ }^{*} \mathrm{p}<0.1$. 
Table 13: Firm-Level Wages and Employment Response to Export Shocks

\begin{tabular}{|c|c|c|c|c|c|}
\hline & \multicolumn{4}{|c|}{$\Delta$ Log Wages $(\mathrm{t})$} & \multirow{2}{*}{$\frac{\Delta \text { Log Employment }(\mathrm{t})}{(5)}$} \\
\hline & $\begin{array}{c}(1) \\
\text { All } \\
\text { Workers }\end{array}$ & $\begin{array}{c}(2) \\
\text { Bot. } 25 \\
\text { Workers }\end{array}$ & $\begin{array}{l}\quad(3) \\
\text { Mid. } 50 \\
\text { Workers }\end{array}$ & $\begin{array}{c}(4) \\
\text { Top } 25 \\
\text { Workers }\end{array}$ & \\
\hline$\Delta$ Export Price $(\mathrm{t}) \mathrm{x}$ Business Group & $\begin{array}{c}0.004 \\
(0.004)\end{array}$ & $\begin{array}{c}0.002 \\
(0.009)\end{array}$ & $\begin{array}{c}0.004 \\
(0.005)\end{array}$ & $\begin{array}{c}0.002 \\
(0.006)\end{array}$ & $\begin{array}{c}-0.016 \\
(0.017)\end{array}$ \\
\hline$\Delta$ Export Price $(\mathrm{t}-1) \mathrm{x}$ Business Group & $\begin{array}{c}0.017^{* * *} \\
(0.005)\end{array}$ & $\begin{array}{c}0.016^{*} \\
(0.010)\end{array}$ & $\begin{array}{c}0.019^{* * *} \\
(0.006)\end{array}$ & $\begin{array}{c}0.015^{* * *} \\
(0.005)\end{array}$ & $\begin{array}{l}-0.040^{*} \\
(0.021)\end{array}$ \\
\hline$\Delta$ Export Price $(\mathrm{t}-2) \mathrm{x}$ Business Group & $\begin{array}{l}0.011^{* *} \\
(0.006)\end{array}$ & $\begin{array}{c}0.005 \\
(0.011)\end{array}$ & $\begin{array}{l}0.015^{* *} \\
(0.006)\end{array}$ & $\begin{array}{c}0.009 \\
(0.006)\end{array}$ & $\begin{array}{l}-0.043^{*} \\
(0.023)\end{array}$ \\
\hline$\Delta$ Export Price $(\mathrm{t}-3) \mathrm{x}$ Business Group & $\begin{array}{c}0.010^{*} \\
(0.006)\end{array}$ & $\begin{array}{c}0.011 \\
(0.010)\end{array}$ & $\begin{array}{c}0.008 \\
(0.008)\end{array}$ & $\begin{array}{l}0.011^{* *} \\
(0.004)\end{array}$ & $\begin{array}{c}-0.041^{* *} \\
(0.021)\end{array}$ \\
\hline$\Delta$ Export Price $(\mathrm{t})$ & $\begin{array}{l}-0.000 \\
(0.002)\end{array}$ & $\begin{array}{c}0.003 \\
(0.004)\end{array}$ & $\begin{array}{l}-0.001 \\
(0.002)\end{array}$ & $\begin{array}{c}0.000 \\
(0.003)\end{array}$ & $\begin{array}{c}0.003 \\
(0.005)\end{array}$ \\
\hline$\Delta$ Export Price $(\mathrm{t}-1)$ & $\begin{array}{c}-0.004^{*} \\
(0.002)\end{array}$ & $\begin{array}{c}-0.002 \\
(0.004)\end{array}$ & $\begin{array}{c}-0.005^{*} \\
(0.003)\end{array}$ & $\begin{array}{c}-0.003 \\
(0.003)\end{array}$ & $\begin{array}{c}0.006 \\
(0.007)\end{array}$ \\
\hline$\Delta$ Export Price $(\mathrm{t}-2)$ & $\begin{array}{c}-0.006^{* * *} \\
(0.002)\end{array}$ & $\begin{array}{c}-0.006 \\
(0.004)\end{array}$ & $\begin{array}{c}-0.007^{* *} \\
(0.003)\end{array}$ & $\begin{array}{c}-0.005^{*} \\
(0.003)\end{array}$ & $\begin{array}{c}0.009 \\
(0.006)\end{array}$ \\
\hline$\Delta$ Export Price $(\mathrm{t}-3)$ & $\begin{array}{c}-0.005^{* * *} \\
(0.002)\end{array}$ & $\begin{array}{l}-0.005 \\
(0.004)\end{array}$ & $\begin{array}{c}-0.005^{* * *} \\
(0.002)\end{array}$ & $\begin{array}{c}-0.004^{*} \\
(0.003)\end{array}$ & $\begin{array}{c}0.005 \\
(0.005)\end{array}$ \\
\hline$R^{2}$ & 0.173 & 0.103 & 0.147 & 0.176 & 0.256 \\
\hline Year FE & $\checkmark$ & $\checkmark$ & $\checkmark$ & $\checkmark$ & $\checkmark$ \\
\hline Firm FE & $\checkmark$ & $\checkmark$ & $\checkmark$ & $\checkmark$ & $\checkmark$ \\
\hline Mean DV & .035 & .026 & .036 & .039 & .068 \\
\hline SD DV & .117 & .219 & .149 & .129 & .304 \\
\hline Number of observations & 6359 & 6359 & 6359 & 6359 & 6359 \\
\hline
\end{tabular}

Notes: This table reports firm-level panel regressions for annual $(\log )$ wage growth of workers in different segments of the wage distribution (All, Bottom 25, Middle 50, Top 25) and total employment. Business Group is a dummy for those firms that are part of a business group. Robust standard errors in parentheses are clustered at the firm level. ${ }^{* * *} \mathrm{p}<0.01,{ }^{* *} \mathrm{p}<0.05,{ }^{*} \mathrm{p}<0.1$. 


\section{Online Appendix}

Figure A.1: Industry Distribution for Different Samples

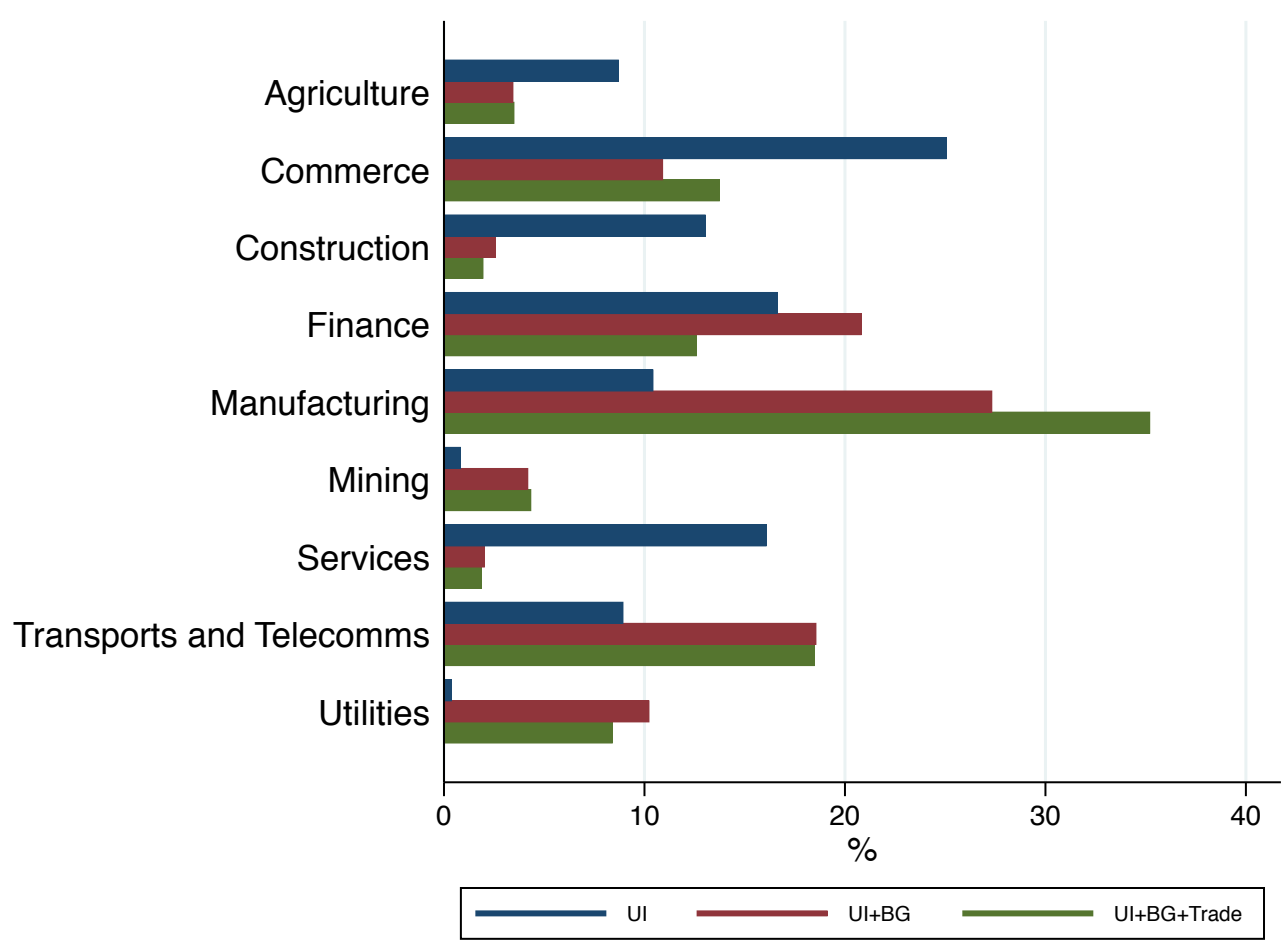

Notes: This figure presents the industry distribution for the full sample of UI (unemployment insurance), the matched sampled between UI and business-group firms (UI-Business Group), and the matched sample between UI, business-group firms, and trade data (UI-Business Group-Trade). 
Figure A.2: Impact of Receiving and Sending a Top-Occupation Worker: Alternative Synthetic Controls

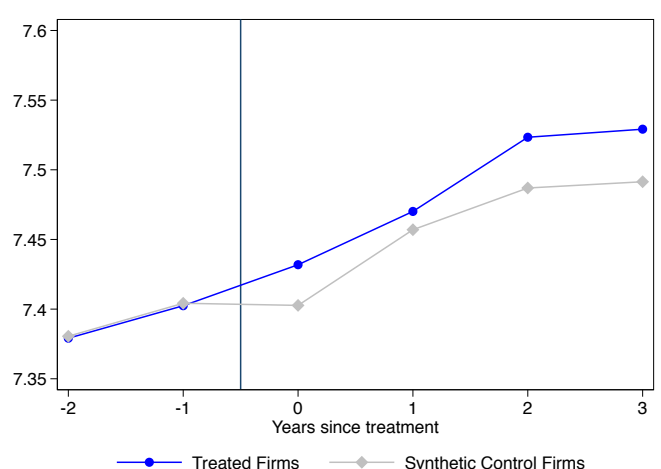

A. Destination Firm: Average wage

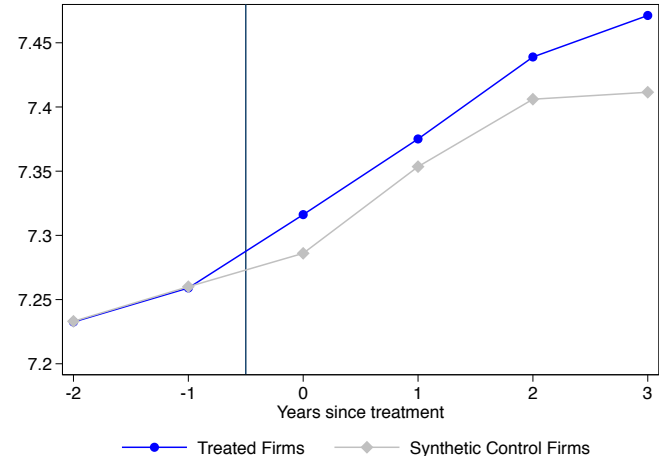

B. Destination Firm's Stayers: Average wage

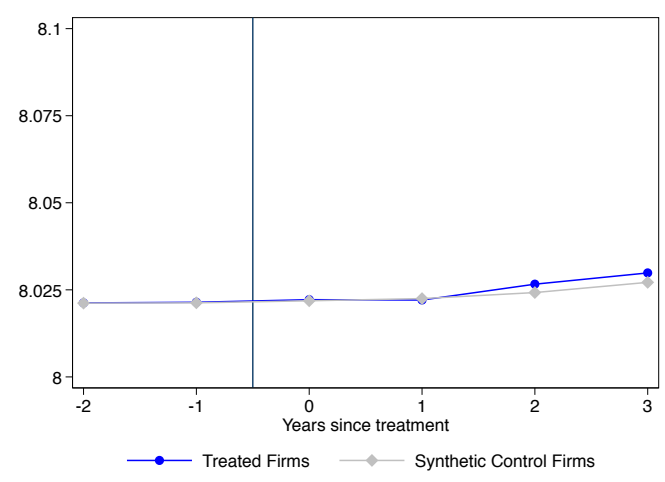

C. Origin Firm: Average wage

Notes: This figure shows the logarithm of average wage (our proxy for productivity) for firms in business groups and for synthetic controls. Treated firms correspond to group firms that receive a top-occupation worker from the same business group (Panels A and B), or group firms that send a top-occupation worker to other firms (Panel C). In Panels A and C average wage is computed using all the workers of the firm, while in Panel B it is computed using workers that worked at the firm before the treatment (stayers). The choice of synthetic controls is discussed in Section 5.2. 
Table A.1: Summary Statistics of International Trade Shocks

\begin{tabular}{|c|c|c|c|c|c|c|c|c|}
\hline & \multicolumn{4}{|c|}{ Imports } & \multicolumn{4}{|c|}{ Exports } \\
\hline & SD & Pr. Large & Pr. Large & Pr. Large & SD & Pr. Large & Pr. Large & Pr. Large \\
\hline & 2004-2015 & 2004-2007 & 2008-2011 & $2012-2015$ & 2004-2015 & 2004-2007 & 2008-2011 & $2012-2015$ \\
\hline & (1) & (2) & (3) & (4) & (5) & (6) & (7) & (8) \\
\hline Agriculture & 0.4 & 1 & 0.6 & 0.1 & 0.4 & 1.4 & 1.1 & 0.2 \\
\hline Commerce & 0.3 & 0.6 & 0.7 & 0.4 & 0.4 & 1 & 0.2 & 0.3 \\
\hline Construction & 0.5 & 1 & 0.7 & 0.3 & 0.1 & 0 & 0 & 0 \\
\hline Finance & 0.5 & 2.2 & 1 & 0.5 & 0.3 & 0.5 & 0.1 & 0 \\
\hline Manufacturing & 0.3 & 1.4 & 0.6 & 0.5 & 0.6 & 2.7 & 0.3 & 0.2 \\
\hline Mining & 0.2 & 0.8 & 0.9 & 0.2 & 0.7 & 3.2 & 1.3 & 0.7 \\
\hline Services & 0.4 & 0.7 & 0.7 & 0.5 & 0.2 & 0 & 0 & 0 \\
\hline TransTelecoms & 0.3 & 1.3 & 0.4 & 0.1 & 0.5 & 0.3 & 0.3 & 0 \\
\hline Utilities & 0.7 & 5.1 & 0 & 0 & 0.3 & 0 & 0 & 0 \\
\hline
\end{tabular}

Notes: This table presents statistics for the export and import price shocks. Columns (1) and (5) report the standard deviation (SD) of firm-level log-changes of import and export prices across time for the whole sample (2004-2015). Columns (2)-(4) and (6)-(8) report the likelihood (Pr) in percentage terms that the import and export shocks are larger than two standard deviations in absolute value for different time frames. Statistics on the mean of both import and export shocks are excluded since they are always zero. 
Table A.2: Summary Statistics of Number of Firms, Workers and Firm Pairs: Sample of Exports and Importers

\begin{tabular}{lrr} 
Number of Firms & $\begin{array}{r}\text { Total } \\
\text { All }\end{array}$ & Mean per Year \\
\hline Business Group & 198,670 & 66,001 \\
Non-Business Group & 198,360 & 236 \\
\hline Number of Workers & Total & Mean per Year \\
\hline All & $6,881,912$ & $3,309,022$ \\
Business Group & 332,851 & 103,308 \\
Non-Business Group & $6,811,616$ & $3,205,714$ \\
\hline Number of Workers per Firm & Total & Mean per Year \\
\hline All & 35 & 50 \\
Business Group & 1,074 & 438 \\
Non-Business Group & 34 & 49 \\
\hline Number of Firm Pairs & Total & Mean per Year \\
\hline Business Group - All & 22,789 & 2,475 \\
Business Group - Business Group & 1,038 & 160 \\
Business Group - Non-Business Group & 21,751 & 2,315 \\
\hline
\end{tabular}

Notes: This table documents, for the sample of firms in the employer-employee dataset that both import and export (which is the one used in the regressions with trade shocks), the number of firms, Business Group firms, non-Business Group firms; the number of workers in all firms, in Business Group and nonBusiness Group firms; the number of firm pairs involved in worker flows starting from Business Group firms and going to both Business Group and non-Business Group firms; and the average number of workers per firm, for all firms, Business Group firms and non-Business Group firms. It reports these stats for both unique values of the whole dataset and also the mean number per year. Note that the number of workers per firm can be obtained by dividing the total number of workers and the number of firms reported in this table. 
Table A.3: Worker Flows Between Pairs of Affiliated and Unaffiliated Firms

\begin{tabular}{|c|c|c|c|c|c|c|}
\hline & \multicolumn{6}{|c|}{ All Workers } \\
\hline & \multicolumn{3}{|c|}{ All Firms } & \multicolumn{3}{|c|}{ Exports \& Imports } \\
\hline & Affiliated & Unaffiliated & $\begin{array}{l}\text { Difference } \\
\text { P-value }\end{array}$ & Affiliated & Unaffiliated & $\begin{array}{c}\text { Difference } \\
\mathrm{P} \text {-value }\end{array}$ \\
\hline & $(1)$ & $(2)$ & (3) & $(4)$ & $(5)$ & (6) \\
\hline \multirow[t]{2}{*}{ Outflows } & 0.115 & 0.021 & $0.094^{* * *}$ & 0.053 & 0.019 & $0.034 * * *$ \\
\hline & $(0.004)$ & $(0.000)$ & {$[0.000]$} & $(0.004)$ & $(0.000)$ & {$[0.000]$} \\
\hline \multirow[t]{6}{*}{ Inflows } & 0.098 & 0.021 & $0.077 * * *$ & 0.043 & 0.018 & $0.026 * * *$ \\
\hline & $(0.004)$ & $(0.000)$ & {$[0.000]$} & $(0.003)$ & $(0.000)$ & {$[0.000]$} \\
\hline & \multicolumn{6}{|c|}{ Top-Occupation Workers } \\
\hline & \multicolumn{3}{|c|}{ All Firms } & \multicolumn{3}{|c|}{ Exports \& Imports } \\
\hline & Affiliated & Unaffiliated & $\begin{array}{c}\text { Difference } \\
\text { P-value }\end{array}$ & Affiliated & Unaffiliated & $\begin{array}{c}\text { Difference } \\
\text { P-value }\end{array}$ \\
\hline & $(1)$ & $(2)$ & $(3)$ & $(4)$ & $(5)$ & $(6)$ \\
\hline \multirow[t]{2}{*}{ Outflows } & 0.294 & 0.112 & $0.182^{* * *}$ & 0.198 & 0.115 & $0.082^{* * *}$ \\
\hline & $(0.010)$ & $(0.001)$ & {$[0.000]$} & $(0.014)$ & $(0.002)$ & {$[0.000]$} \\
\hline \multirow[t]{2}{*}{ Inflows } & 0.197 & 0.090 & $0.107 * * *$ & 0.125 & 0.075 & $0.050 * * *$ \\
\hline & $(0.008)$ & $(0.001)$ & {$[0.000]$} & $(0.010)$ & $(0.001)$ & {$[0.000]$} \\
\hline
\end{tabular}

Notes: This table shows the average worker outflows and inflows between pairs of affiliated and unaffiliated firms. The upper panel presents the average flows for the full sample of workers, while the bottom panel shows the average flows only for top-occupation workers (top quartile of within-firm wage distribution). We restrict the sample of worker outflows (inflows) to pairs of firms in which the sending (receiving) firm belongs to a business group. Exports and Imports corresponds to the sample with firms that simultaneously export and import. Standard errors are presented in parenthesis, while P-values in brackets. 
Table A.4: Summary Statistics of Worker Flows and Wage Changes of Movers

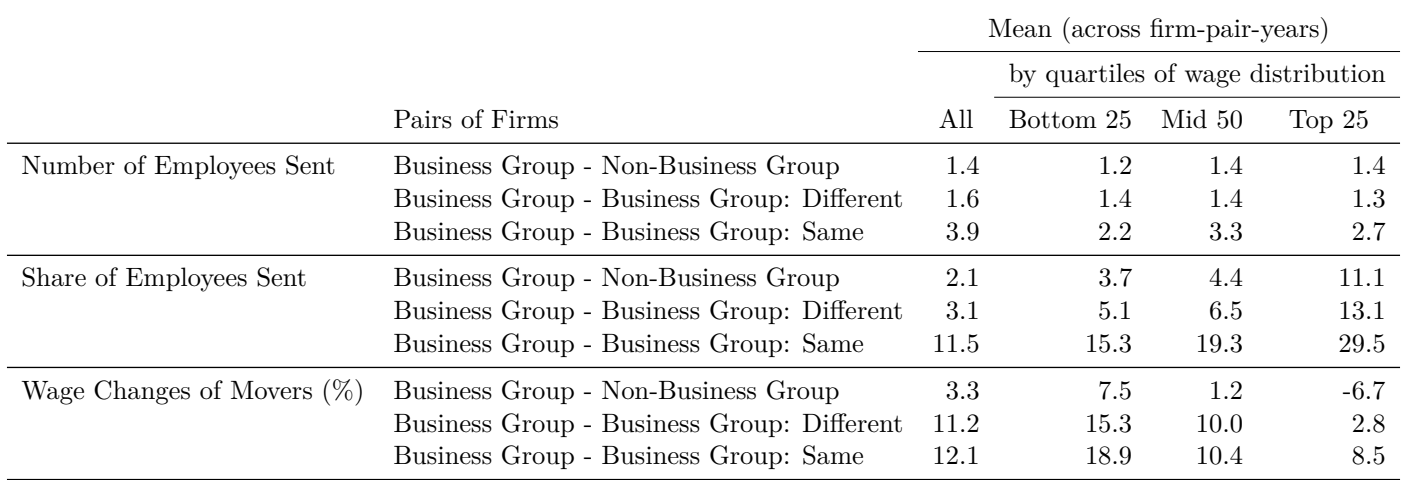

Notes: This table shows statistics of worker flows between firm pairs, averaged across years of the full sample of the employer-employee dataset. It shows both the number of workers sent from Business Group firms to other types of firms, the share of workers sent relative to total number of workers sent by the origin firm, and wage changes of those workers that move between different types of firms. 
Table A.5: Internal Labor Mobility Test: Worker Segments Across the Entire Income Distribution in the Economy

\begin{tabular}{|c|c|c|c|c|}
\hline & $\begin{array}{c}\text { All } \\
\text { Workers }\end{array}$ & $\begin{array}{l}\text { Bot. } 25 \\
\text { Workers }\end{array}$ & $\begin{array}{l}\text { Mid. } 50 \\
\text { Workers }\end{array}$ & $\begin{array}{c}\text { Top } 25 \\
\text { Workers }\end{array}$ \\
\hline & $(1)$ & $(2)$ & $(3)$ & $(4)$ \\
\hline$\Delta$ Export Price x Same Business Group & $\begin{array}{c}0.003^{*} \\
(0.002)\end{array}$ & $\begin{array}{c}0.005^{*} \\
(0.003)\end{array}$ & $\begin{array}{c}0.001 \\
(0.003)\end{array}$ & $\begin{array}{c}0.006 \\
(0.006)\end{array}$ \\
\hline$\Delta$ Import Price x Same Business Group & $\begin{array}{c}-0.004 \\
(0.004)\end{array}$ & $\begin{array}{c}-0.018 \\
(0.012)\end{array}$ & $\begin{array}{c}-0.024^{* * *} \\
(0.009)\end{array}$ & $\begin{array}{c}-0.008 \\
(0.008)\end{array}$ \\
\hline$\Delta$ Export Price & $\begin{array}{c}0.001 \\
(0.001)\end{array}$ & $\begin{array}{c}-0.003^{*} \\
(0.002)\end{array}$ & $\begin{array}{c}0.002 \\
(0.001)\end{array}$ & $\begin{array}{c}0.005^{* * *} \\
(0.002)\end{array}$ \\
\hline$\Delta$ Import Price & $\begin{array}{c}-0.001 \\
(0.001)\end{array}$ & $\begin{array}{c}0.002 \\
(0.002)\end{array}$ & $\begin{array}{c}0.001 \\
(0.001)\end{array}$ & $\begin{array}{l}-0.000 \\
(0.001)\end{array}$ \\
\hline Same Business Group & $\begin{array}{c}0.022^{* * *} \\
(0.006)\end{array}$ & $\begin{array}{c}0.016^{*} \\
(0.009)\end{array}$ & $\begin{array}{c}0.033^{* *} \\
(0.013)\end{array}$ & $\begin{array}{c}0.044^{* * *} \\
(0.011)\end{array}$ \\
\hline Log Avg. Wage Origin & $\begin{array}{c}0.003 \\
(0.018)\end{array}$ & $\begin{array}{c}0.037^{*} \\
(0.019)\end{array}$ & $\begin{array}{c}0.028 \\
(0.027)\end{array}$ & $\begin{array}{c}-0.089 \\
(0.060)\end{array}$ \\
\hline Log Avg. Wage Destination & $\begin{array}{c}0.000 \\
(0.003)\end{array}$ & $\begin{array}{c}-0.000 \\
(0.006)\end{array}$ & $\begin{array}{c}-0.009 \\
(0.006)\end{array}$ & $\begin{array}{c}0.001 \\
(0.020)\end{array}$ \\
\hline Log Employment Destination & $\begin{array}{c}-0.002^{*} \\
(0.001)\end{array}$ & $\begin{array}{l}-0.003 \\
(0.002)\end{array}$ & $\begin{array}{c}-0.004 \\
(0.003)\end{array}$ & $\begin{array}{c}-0.010^{*} \\
(0.005)\end{array}$ \\
\hline Log Employment Origin & $\begin{array}{c}-0.046^{* * *} \\
(0.009)\end{array}$ & $\begin{array}{c}-0.065^{* * *} \\
(0.015)\end{array}$ & $\begin{array}{c}-0.068^{* * *} \\
(0.014)\end{array}$ & $\begin{array}{c}-0.080^{* * *} \\
(0.020)\end{array}$ \\
\hline Log Emp. Business Group Origin & $\begin{array}{c}-0.095 \\
(0.082)\end{array}$ & $\begin{array}{c}-0.033 \\
(0.120)\end{array}$ & $\begin{array}{c}-0.150^{* *} \\
(0.060)\end{array}$ & $\begin{array}{c}0.112 \\
(0.139)\end{array}$ \\
\hline Log Emp. Business Group Destination & $\begin{array}{c}-0.123^{* *} \\
(0.049)\end{array}$ & $\begin{array}{c}-0.130 \\
(0.111)\end{array}$ & $\begin{array}{c}-0.178^{*} \\
(0.106)\end{array}$ & $\begin{array}{l}-0.115 \\
(0.175)\end{array}$ \\
\hline Log N. Firms Business Group Origin & $\begin{array}{c}0.061^{* *} \\
(0.030)\end{array}$ & $\begin{array}{c}0.031 \\
(0.025)\end{array}$ & $\begin{array}{c}0.073^{*} \\
(0.037)\end{array}$ & $\begin{array}{c}0.282^{* *} \\
(0.129)\end{array}$ \\
\hline Log N. Firms Business Group Destination & $\begin{array}{c}0.010 \\
(0.015)\end{array}$ & $\begin{array}{c}0.036 \\
(0.036)\end{array}$ & $\begin{array}{c}0.028 \\
(0.030)\end{array}$ & $\begin{array}{c}0.080 \\
(0.090)\end{array}$ \\
\hline$R^{2}$ & 0.594 & 0.801 & 0.664 & 0.685 \\
\hline Origin FE & $\checkmark$ & $\checkmark$ & $\checkmark$ & $\checkmark$ \\
\hline Destination FE & $\checkmark$ & $\checkmark$ & $\checkmark$ & $\checkmark$ \\
\hline Year FE & $\checkmark$ & $\checkmark$ & $\checkmark$ & $\checkmark$ \\
\hline Mean DV & .02 & .039 & .042 & .067 \\
\hline SD DV & .042 & .085 & .076 & .111 \\
\hline Number of observations & 20253 & 6259 & 7532 & 5083 \\
\hline
\end{tabular}

Notes: This table reports the results from the regression in Equation (3.2), but using the entire income distribution of the country to define worker segments. $\Delta$ Exports ( $\Delta$ Imports) is defined as the log difference in firm-level export (imports) prices between two consecutive years and between the destination and the origin firm (see Section 2.3). See Table 3 for variable definitions. Robust standard errors in parentheses are double clustered at the level of the firm of origin and destination of the flow. $* * * \mathrm{p}<0.01,{ }^{* *} \mathrm{p}<0.05$, $* \mathrm{p}<0.1$. 
Table A.6: Internal Labor Mobility Test: Using Worker Inflows

\begin{tabular}{|c|c|c|c|c|c|c|}
\hline & $\begin{array}{c}\text { All } \\
\text { Workers }\end{array}$ & $\begin{array}{l}\text { Bot. } 25 \\
\text { Workers }\end{array}$ & $\begin{array}{l}\text { Mid. } 50 \\
\text { Workers }\end{array}$ & $\begin{array}{c}\text { Top } 25 \\
\text { Workers }\end{array}$ & $\begin{array}{c}\text { Top } 20 \\
\text { Workers }\end{array}$ & $\begin{array}{c}\text { Top } 10 \\
\text { Workers } \\
\end{array}$ \\
\hline & $(1)$ & $(2)$ & $(3)$ & $(4)$ & $(5)$ & $(6)$ \\
\hline$\Delta$ Export Price $\mathrm{x}$ Same Business Group & $\begin{array}{c}0.002 \\
(0.001)\end{array}$ & $\begin{array}{l}-0.002 \\
(0.002)\end{array}$ & $\begin{array}{c}0.004 \\
(0.003)\end{array}$ & $\begin{array}{l}0.015^{*} \\
(0.009)\end{array}$ & $\begin{array}{l}0.014^{*} \\
(0.007)\end{array}$ & $\begin{array}{l}0.029^{*} \\
(0.016)\end{array}$ \\
\hline$\Delta$ Import Price x Same Business Group & $\begin{array}{l}-0.005 \\
(0.711)\end{array}$ & $\begin{array}{c}0.004 \\
(0.712)\end{array}$ & $\begin{array}{c}-0.011 \\
(0.043)\end{array}$ & $\begin{array}{l}-0.007 \\
(0.009)\end{array}$ & $\begin{array}{c}-0.002 \\
(0.001)\end{array}$ & $\begin{array}{l}-0.005 \\
(1.438)\end{array}$ \\
\hline$\Delta$ Export Price & $\begin{array}{l}-0.000 \\
(0.000)\end{array}$ & $\begin{array}{c}0.000 \\
(0.001)\end{array}$ & $\begin{array}{l}-0.000 \\
(0.001)\end{array}$ & $\begin{array}{l}-0.002 \\
(0.002)\end{array}$ & $\begin{array}{l}-0.002 \\
(0.002)\end{array}$ & $\begin{array}{l}-0.003 \\
(0.004)\end{array}$ \\
\hline$\Delta$ Import Price & $\begin{array}{l}-0.000 \\
(0.000)\end{array}$ & $\begin{array}{c}0.001 \\
(0.001)\end{array}$ & $\begin{array}{c}-0.001 \\
(0.001)\end{array}$ & $\begin{array}{c}0.002 \\
(0.002)\end{array}$ & $\begin{array}{l}0.004^{*} \\
(0.002)\end{array}$ & $\begin{array}{l}0.006^{*} \\
(0.004)\end{array}$ \\
\hline Same Business Group & $\begin{array}{c}0.021^{* * *} \\
(0.004)\end{array}$ & $\begin{array}{c}0.023^{* * *} \\
(0.007)\end{array}$ & $\begin{array}{l}0.017^{* *} \\
(0.007)\end{array}$ & $\begin{array}{c}0.036^{* * *} \\
(0.012)\end{array}$ & $\begin{array}{l}0.038^{* *} \\
(0.017)\end{array}$ & $\begin{array}{c}0.023 \\
(0.021)\end{array}$ \\
\hline Log Avg. Wage Origin & $\begin{array}{l}-0.000 \\
(0.002)\end{array}$ & $\begin{array}{l}-0.002 \\
(0.008)\end{array}$ & $\begin{array}{l}-0.006 \\
(0.006)\end{array}$ & $\begin{array}{c}0.014 \\
(0.012)\end{array}$ & $\begin{array}{c}0.013 \\
(0.014)\end{array}$ & $\begin{array}{l}0.044^{*} \\
(0.025)\end{array}$ \\
\hline Log Avg. Wage Destination & $\begin{array}{c}0.006 \\
(0.008)\end{array}$ & $\begin{array}{c}0.008 \\
(0.014)\end{array}$ & $\begin{array}{c}-0.002 \\
(0.011)\end{array}$ & $\begin{array}{c}0.017 \\
(0.034)\end{array}$ & $\begin{array}{c}0.030 \\
(0.040)\end{array}$ & $\begin{array}{l}-0.030 \\
(0.079)\end{array}$ \\
\hline Log Employment Destination & $\begin{array}{l}-0.003 \\
(0.003)\end{array}$ & $\begin{array}{c}-0.003 \\
(0.006)\end{array}$ & $\begin{array}{c}-0.008 \\
(0.005)\end{array}$ & $\begin{array}{c}-0.001 \\
(0.011)\end{array}$ & $\begin{array}{c}-0.002 \\
(0.012)\end{array}$ & $\begin{array}{l}-0.012 \\
(0.016)\end{array}$ \\
\hline Log Employment Origin & $\begin{array}{c}0.003^{* * *} \\
(0.001)\end{array}$ & $\begin{array}{c}0.002 \\
(0.002)\end{array}$ & $\begin{array}{l}0.003^{* *} \\
(0.002)\end{array}$ & $\begin{array}{c}0.013^{* * *} \\
(0.005)\end{array}$ & $\begin{array}{l}0.012^{* *} \\
(0.006)\end{array}$ & $\begin{array}{c}0.016 \\
(0.011)\end{array}$ \\
\hline Log Emp. Business Group Origin & $\begin{array}{c}-0.081^{* *} \\
(0.036)\end{array}$ & $\begin{array}{l}-0.125 \\
(0.114)\end{array}$ & $\begin{array}{l}-0.070 \\
(0.056)\end{array}$ & $\begin{array}{c}-0.311^{* *} \\
(0.130)\end{array}$ & $\begin{array}{l}-0.268 \\
(0.173)\end{array}$ & $\begin{array}{l}-0.272 \\
(0.362)\end{array}$ \\
\hline Log Emp. Business Group Dest. & $\begin{array}{c}-0.136^{* * *} \\
(0.049)\end{array}$ & $\begin{array}{c}-0.478^{* * *} \\
(0.152)\end{array}$ & $\begin{array}{c}-0.306^{* * *} \\
(0.099)\end{array}$ & $\begin{array}{l}-0.209 \\
(0.152)\end{array}$ & $\begin{array}{c}-0.088 \\
(0.169)\end{array}$ & $\begin{array}{l}-0.161 \\
(0.463)\end{array}$ \\
\hline Log N. Firms Business Group Origin & $\begin{array}{c}0.005 \\
(0.017)\end{array}$ & $\begin{array}{c}0.021 \\
(0.025)\end{array}$ & $\begin{array}{c}-0.051^{*} \\
(0.028)\end{array}$ & $\begin{array}{l}0.241^{* *} \\
(0.121)\end{array}$ & $\begin{array}{l}0.342^{* *} \\
(0.149)\end{array}$ & $\begin{array}{c}0.635 \\
(0.462)\end{array}$ \\
\hline Log N. Firms Business Group Dest. & $\begin{array}{l}-0.010 \\
(0.022)\end{array}$ & $\begin{array}{c}0.033 \\
(0.036)\end{array}$ & $\begin{array}{c}0.007 \\
(0.037)\end{array}$ & $\begin{array}{c}0.001 \\
(0.089)\end{array}$ & $\begin{array}{l}-0.009 \\
(0.095)\end{array}$ & $\begin{array}{l}-0.226 \\
(0.225)\end{array}$ \\
\hline$R^{2}$ & 0.591 & 0.615 & 0.633 & 0.682 & 0.700 & 0.734 \\
\hline Origin FE & $\checkmark$ & $\checkmark$ & $\checkmark$ & $\checkmark$ & $\checkmark$ & $\checkmark$ \\
\hline Destination FE & $\checkmark$ & $\checkmark$ & $\checkmark$ & $\checkmark$ & $\checkmark$ & $\checkmark$ \\
\hline Year FE & $\checkmark$ & $\checkmark$ & $\checkmark$ & $\checkmark$ & $\checkmark$ & $\checkmark$ \\
\hline Mean DV & .019 & .044 & .036 & .079 & .095 & .149 \\
\hline SD DV & .039 & .075 & .065 & .112 & .131 & .174 \\
\hline Mean Numerator DV & 1.7 & 1.2 & 1.8 & 1.3 & 1.2 & 1.4 \\
\hline Number of observations & 22343 & 7731 & 10082 & 3851 & 3137 & 1531 \\
\hline
\end{tabular}

Notes: This table reports the results from the regression in Equation (3.2) with the difference that the dependant variable is now the number of workers that move from origin firm $o$ to destination firm $d$ at time $t$ relative to the number of workers that move from any firm to destination firm $d$ at time $t$. $\Delta$ Exports $(\Delta$ Imports) is defined as the log difference in firm-level export (imports) prices between two consecutive years and between the destination and the origin firms (see Section 2.3). See Table 3 for variable definitions. Robust standard errors in parentheses are double clustered at the level of the firm of origin and destination of the flow. ${ }^{* * *} \mathrm{p}<0.01,{ }^{* *} \mathrm{p}<0.05,{ }^{*} \mathrm{p}<0.1$. 
Table A.7: Extensive Margin of Worker Flows

\begin{tabular}{|c|c|c|c|c|c|c|}
\hline & $\begin{array}{c}\text { All } \\
\text { Workers }\end{array}$ & $\begin{array}{l}\text { Bot. } 25 \\
\text { Workers }\end{array}$ & $\begin{array}{l}\text { Mid. } 50 \\
\text { Workers }\end{array}$ & $\begin{array}{c}\text { Top } 25 \\
\text { Workers }\end{array}$ & $\begin{array}{c}\text { Top } 20 \\
\text { Workers }\end{array}$ & $\begin{array}{c}\text { Top } 10 \\
\text { Workers }\end{array}$ \\
\hline & $(1)$ & $(2)$ & $(3)$ & $(4)$ & $(5)$ & $(6)$ \\
\hline$\Delta$ Export Price $\mathrm{x}$ Same Business Group & $\begin{array}{c}0.121 \\
(0.207)\end{array}$ & $\begin{array}{l}0.373^{* *} \\
(0.148)\end{array}$ & $\begin{array}{l}-0.207 \\
(0.137)\end{array}$ & $\begin{array}{l}0.266^{* *} \\
(0.125)\end{array}$ & $\begin{array}{l}0.242^{*} \\
(0.127)\end{array}$ & $\begin{array}{l}0.122^{*} \\
(0.067)\end{array}$ \\
\hline$\Delta$ Import Price $\mathrm{x}$ Same Business Group & $\begin{array}{l}-0.036 \\
(0.212)\end{array}$ & $\begin{array}{c}0.089 \\
(0.088)\end{array}$ & $\begin{array}{l}-0.008 \\
(0.132)\end{array}$ & $\begin{array}{l}-0.097 \\
(0.152)\end{array}$ & $\begin{array}{l}-0.108 \\
(0.133)\end{array}$ & $\begin{array}{c}-0.224^{* *} \\
(0.107)\end{array}$ \\
\hline$\Delta$ Export Price & $\begin{array}{c}0.003 \\
(0.005)\end{array}$ & $\begin{array}{c}0.001 \\
(0.003)\end{array}$ & $\begin{array}{c}0.003 \\
(0.003)\end{array}$ & $\begin{array}{l}-0.000 \\
(0.002)\end{array}$ & $\begin{array}{l}-0.000 \\
(0.002)\end{array}$ & $\begin{array}{c}0.000 \\
(0.001)\end{array}$ \\
\hline$\Delta$ Import Price & $\begin{array}{l}-0.001 \\
(0.003)\end{array}$ & $\begin{array}{l}-0.003 \\
(0.002)\end{array}$ & $\begin{array}{c}0.001 \\
(0.002)\end{array}$ & $\begin{array}{c}0.001 \\
(0.001)\end{array}$ & $\begin{array}{c}0.001 \\
(0.001)\end{array}$ & $\begin{array}{l}0.000 \\
(0.001)\end{array}$ \\
\hline Same Business Group & $\begin{array}{c}5.053^{* * *} \\
(0.694)\end{array}$ & $\begin{array}{c}2.317^{* * *} \\
(0.445)\end{array}$ & $\begin{array}{c}2.579^{* * *} \\
(0.481)\end{array}$ & $\begin{array}{c}2.528^{* * *} \\
(0.373)\end{array}$ & $\begin{array}{c}2.312^{* * * *} \\
(0.354)\end{array}$ & $\begin{array}{c}1.528^{* * *} \\
(0.246)\end{array}$ \\
\hline Log Avg. Wage Origin & $\begin{array}{l}0.155^{* *} \\
(0.077)\end{array}$ & $\begin{array}{l}0.048^{* *} \\
(0.024)\end{array}$ & $\begin{array}{c}0.040 \\
(0.027)\end{array}$ & $\begin{array}{c}0.038 \\
(0.025)\end{array}$ & $\begin{array}{c}0.033 \\
(0.021)\end{array}$ & $\begin{array}{c}0.013 \\
(0.012)\end{array}$ \\
\hline Log Avg. Wage Destination & $\begin{array}{c}0.022 \\
(0.024)\end{array}$ & $\begin{array}{c}0.002 \\
(0.011)\end{array}$ & $\begin{array}{c}0.004 \\
(0.014)\end{array}$ & $\begin{array}{l}-0.005 \\
(0.006)\end{array}$ & $\begin{array}{l}-0.005 \\
(0.004)\end{array}$ & $\begin{array}{c}-0.008^{* * *} \\
(0.003)\end{array}$ \\
\hline Log Employment Destination & $\begin{array}{c}0.161^{* * *} \\
(0.026)\end{array}$ & $\begin{array}{c}0.084^{* * *} \\
(0.015)\end{array}$ & $\begin{array}{c}0.070^{* * *} \\
(0.013)\end{array}$ & $\begin{array}{c}0.037^{* * *} \\
(0.007)\end{array}$ & $\begin{array}{c}0.031^{* * *} \\
(0.006)\end{array}$ & $\begin{array}{c}0.016^{* * * *} \\
(0.004)\end{array}$ \\
\hline Log Employment Origin & $\begin{array}{c}0.151^{* * *} \\
(0.022)\end{array}$ & $\begin{array}{c}0.072^{* * *} \\
(0.013)\end{array}$ & $\begin{array}{c}0.056^{* * *} \\
(0.009)\end{array}$ & $\begin{array}{c}0.042^{* * *} \\
(0.006)\end{array}$ & $\begin{array}{c}0.035^{* * *} \\
(0.005)\end{array}$ & $\begin{array}{c}0.020^{* * *} \\
(0.003)\end{array}$ \\
\hline Log Emp. Business Group Origin & $\begin{array}{l}-0.154 \\
(0.198)\end{array}$ & $\begin{array}{c}-0.003 \\
(0.132)\end{array}$ & $\begin{array}{c}-0.091 \\
(0.089)\end{array}$ & $\begin{array}{l}-0.076^{*} \\
(0.045)\end{array}$ & $\begin{array}{l}-0.054 \\
(0.037)\end{array}$ & $\begin{array}{c}-0.048^{* *} \\
(0.022)\end{array}$ \\
\hline Log Emp. Business Group Destination & $\begin{array}{l}3.561^{*} \\
(1.907)\end{array}$ & $\begin{array}{l}1.566^{*} \\
(0.877)\end{array}$ & $\begin{array}{l}1.658^{*} \\
(0.919)\end{array}$ & $\begin{array}{l}1.341^{*} \\
(0.728)\end{array}$ & $\begin{array}{l}1.198^{*} \\
(0.659)\end{array}$ & $\begin{array}{l}0.822^{*} \\
(0.448)\end{array}$ \\
\hline Log N. Firms Business Group Origin & $\begin{array}{c}0.407 \\
(0.305)\end{array}$ & $\begin{array}{l}0.290^{*} \\
(0.149)\end{array}$ & $\begin{array}{c}0.125 \\
(0.141)\end{array}$ & $\begin{array}{c}0.045 \\
(0.079)\end{array}$ & $\begin{array}{c}0.036 \\
(0.068)\end{array}$ & $\begin{array}{c}0.052 \\
(0.041)\end{array}$ \\
\hline Log N. Firms Business Group Destination & $\begin{array}{c}-2.682^{* *} \\
(1.124) \\
\end{array}$ & $\begin{array}{c}-1.192^{* *} \\
(0.502) \\
\end{array}$ & $\begin{array}{l}-1.155^{*} \\
(0.666)\end{array}$ & $\begin{array}{l}-0.623 \\
(0.541)\end{array}$ & $\begin{array}{l}-0.529 \\
(0.468)\end{array}$ & $\begin{array}{l}-0.109 \\
(0.273)\end{array}$ \\
\hline$R^{2}$ & 0.029 & 0.016 & 0.017 & 0.014 & 0.013 & 0.008 \\
\hline Origin FE & $\checkmark$ & $\checkmark$ & $\checkmark$ & $\checkmark$ & $\checkmark$ & $\checkmark$ \\
\hline Destination FE & $\checkmark$ & $\checkmark$ & $\checkmark$ & $\checkmark$ & $\checkmark$ & $\checkmark$ \\
\hline Year FE & $\checkmark$ & $\checkmark$ & $\checkmark$ & $\checkmark$ & $\checkmark$ & $\checkmark$ \\
\hline Mean DV & .251 & .115 & .112 & .059 & .05 & .027 \\
\hline SD DV & 5.009 & 3.401 & 3.349 & 2.441 & 2.245 & 1.671 \\
\hline Number of observations & 4188243 & 4171227 & 4186565 & 4188243 & 4188243 & 4188243 \\
\hline
\end{tabular}

Notes: This table presents evidence of how the extensive margin of worker flows between firms reacts to international price shocks. The left-hand-side variable is a dummy equal to one when there is a positive worker flow between two pairs of firms in the economy. To keep dimensionality tractable, the sample in these regressions includes only pairs of firms in or across industries that account for the largest share of worker flows in the economy. As with the regressions of the intensive margin, these regressions are conditional on the origin firm belonging to a business group. Because the share of active relationships between firms is small, the dummy is rescaled from $(0,1)$ to $(0,100)$. Robust standard errors in parentheses are double clustered at the level of the firm that sends and receives the flow. $* * * \mathrm{p}<0.01, * * \mathrm{p}<0.05, *$ $\mathrm{p}<0.1$ 


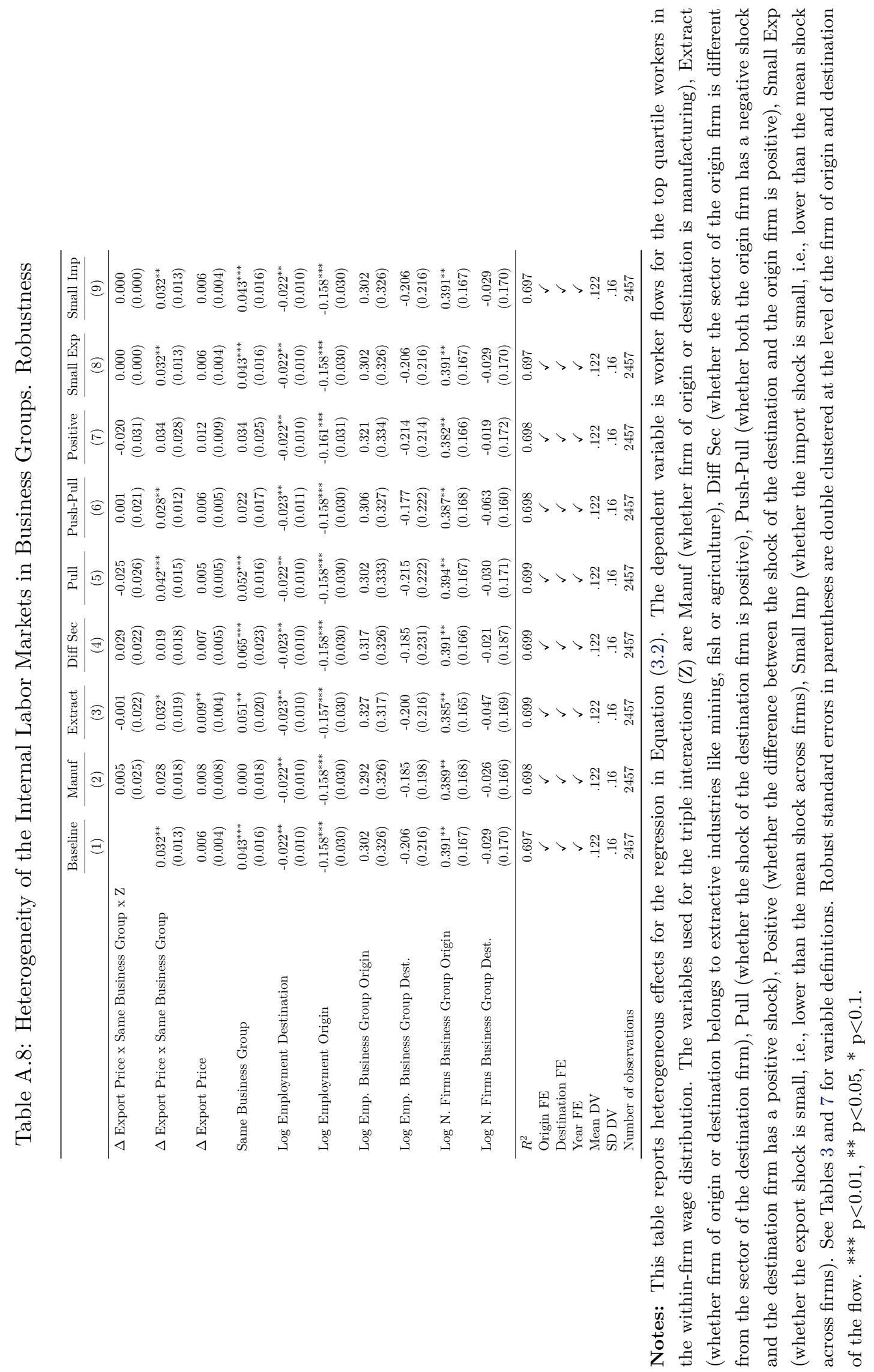


Table A.9: Placebo Confidence Intervals for Synthetic Control Test

\begin{tabular}{lccc}
\hline & $\begin{array}{c}(1) \\
\text { Destination Firm } \\
\text { All Workers }\end{array}$ & $\begin{array}{c}(2) \\
\text { Destination Firm } \\
\text { Stayers }\end{array}$ & $\begin{array}{c}(3) \\
\text { Origin Firm }\end{array}$ \\
\cline { 2 - 4 } & Panel A & Panel B & Panel C \\
& (Figure 3) & (Figure 3) & (Figure 3) \\
Number of treated units & 92 & & 60 \\
Potential controls & 2,985 & 2,985 & 131 \\
Average effect & 0.123 & 0.094 & 0.023 \\
CI 99\% & {$[-0.006,0.002]$} & {$[-0.001,0.070]$} & {$[-0.13,0.52]$} \\
CI 95\% & {$[-0.002,0.001]$} & {$[-0.000,0.007]$} & {$[-0.12,0.41]$} \\
& & & \\
& Panel A & Panel B & Panel C \\
& $($ Figure A.2) & $($ Figure A.2) & $($ Figure A.2) \\
Number of treated units & 92 & 92 & 189 \\
Potential controls & 19,195 & 19,195 & 19,538 \\
Average effect & 0.029 & 0.036 & 0.001 \\
CI 99\% & {$[-0.002,0.034]$} & {$[-0.042,0.016]$} & {$[-0.004,0.0004]$} \\
CI 95\% & {$[-0.002,0.013]$} & {$[-0.042,0.016]$} & {$[-0.004,0.0004]$} \\
\hline
\end{tabular}

Notes: This table presents treatment effects on log average wages for origin and destination firms against synthetic controls. Columns (1) and (3) show the treatment effects for the average wage of all workers, while Column (2) presents the average wage of workers that worked at the firm before the arrival of the new top-occupation worker. In square brackets we present confidence intervals at $5 \%$ and $1 \%$. Confidence intervals are based on placebo treatment groups in 100 random samples. The choice of synthetic controls is discussed in Section 5.2. 